\title{
Curcumin and Its Derivatives as Theranostic Agents in Alzheimer's Disease: The Implication of Nanotechnology
}

\author{
Umair Shabbir (1), Momna Rubab, Akanksha Tyagi and Deog-Hwan Oh * \\ Department of Food Science and Biotechnology, College of Agriculture and Life Sciences, \\ Kangwon National University, Chuncheon 200-701, Korea; umair336@gmail.com (U.S.); \\ rubab.momna@gmail.com (M.R.); akanksha.tyagi001@gmail.com (A.T.) \\ * Correspondence: deoghwa@kangwon.ac.kr
}

check for updates

Citation: Shabbir, U.; Rubab, M.;

Tyagi, A.; Oh, D.-H. Curcumin and

Its Derivatives as Theranostic

Agents in Alzheimer's Disease:

The Implication of Nanotechnology.

Int. J. Mol. Sci. 2021, 22, 196.

https://dx.doi.org/10.3390/

ijms22010196

Received: 10 November 2020

Accepted: 24 December 2020

Published: 27 December 2020

Publisher's Note: MDPI stays neutral with regard to jurisdictional claims in published maps and institutional affiliations.

Copyright: (c) 2020 by the authors. Licensee MDPI, Basel, Switzerland. This article is an open access article distributed under the terms and conditions of the Creative Commons Attribution (CC BY) license (https: / / creativecommons.org/ licenses/by/4.0/).

\begin{abstract}
Curcumin is a polyphenolic natural compound with diverse and attractive biological properties, which may prevent or ameliorate pathological processes underlying age-related cognitive decline, Alzheimer's disease (AD), dementia, or mode disorders. AD is a chronic neurodegenerative disorder that is known as one of the rapidly growing diseases, especially in the elderly population. Moreover, being the eminent cause of dementia, posing problems for families, societies as well a severe burden on the economy. There are no effective drugs to cure AD. Although curcumin and its derivatives have shown properties that can be considered useful in inhibiting the hallmarks of AD, however, they have low bioavailability. Furthermore, to combat diagnostic and therapeutic limitations, various nanoformulations have also been recognized as theranostic agents that can also enhance the pharmacokinetic properties of curcumin and other bioactive compounds. Nanocarriers have shown beneficial properties to deliver curcumin and other nutritional compounds against the blood-brain barrier to efficiently distribute them in the brain. This review spotlights the role and effectiveness of curcumin and its derivatives in AD. Besides, the gut metabolism of curcumin and the effects of nanoparticles and their possible activity as diagnostic and therapeutic agents in AD also discussed.
\end{abstract}

Keywords: neurodegenerative disorder; curcumin; nanoparticles; diagnosis; therapeutic

\section{Introduction}

Globally, mental disorders are one of the main reasons for disability and pointing concerns for public health issues [1]. In 2010,16.2\% of the world population consisted of people aged 65 or over, a figure that is expected to rise up to $26.9 \%$ by 2050 . Increasing life expectancy highlights the importance of physical and mental health in old age. Aging is a very complex process that alters an individual's normal functioning resulting in deterioration of biological functions, especially brain and cognitive functions over a long period. Previous studies have generated inconsistent findings of the prevalence of mental illness among older adults [2]. Due to their higher prevalence, mental problems are contributing to significant health, economic and social burden [3]. Previous studies tended to focus on selective disorders such as dementia or depression, implying that the entire range of mental disorders has been insufficiently addressed [4]. Dementia is a syndrome (or group of symptoms) that causes deterioration in behavior, ability to perform everyday activities, thinking, memory, and learning capacity, language, and judgement. Dementia is not a normal part of aging but generally affects old age people [5]. Among the different kinds of dementia, the most common form is Alzheimer's disease (AD) [6] and may contribute to $60-80 \%$ of cases [7]. According to WHO [5], AD and other types of dementia are the 5th prominent reason for deaths in the world and become a growing public health concern, with about 10 million new cases every year across the world and it is estimated that the frequency will be doubled by 2030 and tripled by 2050 [8]. The conditions worsen over the years, to the point, people suffering from AD may have difficulty in 
remembering events, names, or recent conversations and can have depression in very early stages. Later these symptoms lead to behavioral changes, confusion, impaired communication, poor judgment, disorientation, and ultimately patients are facing difficulty in walking, swallowing, and speaking [7]. There are two major hallmarks of $\mathrm{AD}$ as follows; (1) development of amyloidal plaques outside the cells nerve due to cleavage of membrane-embedded proteins (amyloid precursor proteins: APP) into the neurotoxic single amyloidal units (amyloid-beta: $A \beta$ ) peptides during proteolytic processing by secretases enzymes, such as $\beta$ and $\gamma$-secretase, and (2) formation of neurofibrillary tangles (NFTs) inside the nerve cells due to accumulation of paired helical filaments of hyperphosphorylated tau proteins [6]. A $\beta$ oligomers are the small and soluble aggregates of $A \beta$-peptide are considered as the key pathogenic structures in AD [9-11]. Despite A $\beta$-tau hypothesis; vascular abnormalities, oxidative stress, neuroinflammation, mitochondrial damage, etc. are also contributing to the pathogenesis of $\mathrm{AD}$ [12].

Mitochondria is the essential component of a cell that plays role in cell energy production and pursuing the nutrient-sensing and growth signals within nerve cells [13]. Recently, studies have been exposed that oxidative stress in mitochondrial microglia has also played a part in the development of AD. Loss of mitochondrial membrane potential and elevated generation of reactive oxygen species (ROS) through various mechanisms have been observed in AD. Higher ROS in microglia cause inflammation and activating cell pathways of cell death [14]. Available medicinal treatments or strategies bring only symptomatic benefits, and still, there is no perfect/ideal cure for AD [15]. Therefore, the lack of effective pharmacology therapy has led researchers to seek alternative approaches to treat or prevent $\mathrm{AD}$ such as diet, because nutrients are important for everyday systematic function. Many epidemiological evidence suggest a strong correlation among lifestyle factors, diet, and the onset and consolidation of $\mathrm{AD}$ and other kinds of dementia. Moreover, it has been proven that metabolic syndromes and disorders like insulin resistance, obesity, cardiovascular diseases, diabetes, and AD are strongly related. Nutritional interventions and other preventive strategies can be effective approaches to stop or delay the risk of $\mathrm{AD}$, cognitive decline and other non-psychiatric comorbidities. Many nutrients play a role in biochemical reactions; however, intake of a diet rich in probiotics, antioxidants, plant-based foods, $\omega-3$ polyunsaturated fatty acids, soybeans, and nuts can be beneficial in mitigating AD. Furthermore, less consumption of animal-derived proteins, refined sugars, and low intake of saturated fats can also be useful in this regard [16]. Plant-based polyphenols (including curcumin) have been recognized as potent agents that can help lower down the effects of AD. Curcumin and its derivatives have potential to ameliorate the hallmarks of $\mathrm{AD}$ and other neurodegenerative diseases but still, clinical studies are required to prove this fact. This review summarizes the role of curcumin and its derivatives those have been beneficially associated with the upkeep of neurocognitive capacity and the risk of AD. Association of gut metabolism and curcumin to ameliorate the effects of AD and the effects of nanoformulations as theranostic agents (diagnosis and therapeutic) with the possible role and action in $\mathrm{AD}$ are also explored.

\section{Curcumin}

Curcumin (Curcuma longa L.) commonly known as turmeric belongs to Zingiberaceae (or ginger family) is a bright yellow plant pigment, a popular spice, and food additive widely used in South Asian and Middle Eastern countries [17]. Zingiberaceae is a family of flowering plants which is a rhizomatous herbaceous perennial known as Angiosperms. The powdered rhizome (of turmeric) is used in traditional medicine to cure various kinds of maladies as well as a coloring agent in beverage industries [18]. Compositionally, three main compounds of curcumin (1,7-bis[4-hydroxy-3-methoxyphenyl]-1,6-heptadiene-3,5-dione) are curcuminoid complex (80\%), dimethoxy-curcumin (17\%, 1,7-bis(3,4-dimethoxyphenyl)-1,6-heptadiene3,5-dione) and bisdemethoxy-curcumin (3\%, 1,7-Bis(4-hydroxyphenyl)-1,6-heptadiene-3,5dione) [19]. Modern medicine has shown that curcumin exhibits a broad range of biological and pharmacological activities, including antioxidant [20], anti-inflammatory [21], 
anti-tumor and chemosensitizing [22], hepatoprotective [23], lipid-modifying [24] and neuroprotective [25] effects and are suggested to improve mental illnesses due to its ability to modulate numerous signaling molecules $[8,26,27]$. Many studies show that it is safe to consume $8 \mathrm{~g}$ per day of curcumin $[28,29]$. Therefore, many curcumin based products are available such as tablets, capsules, and as an additive to various energy drinks [27].

\subsection{Curcumin and $A \beta$}

It has been mentioned above and also evident from several studies that the formation of $\mathrm{A} \beta$ plaques is the beginning of the onset of $\mathrm{AD}$. Thus, inhibition or hindrance of these plaques can be useful to deal with $\mathrm{AD}$. Curcumin is proposed to be resistant to $\mathrm{A} \beta$ aggregation as has a higher binding affinity to $A \beta[30]$ and its derivatives are also considered as principal candidates to prevent the aggregation of amyloid plaques. Qin et al. [31] in their work regarding detection strategies of AD disclosed that curcumin has potential to bind $A \beta$ and iron in plaques through intermolecular hydrogen bonds without the combination of any other chemical linkages or bonding. Molecular chains of curcumin have symmetrical methoxyl and phenyl groups. These groups can easily bind amyloid plaques via hydrophobic interactions with nonpolar sections of the amyloid plaques. Further, these can be stabilized by di-ketone and hydroxyl groups of curcumin with polar sections of $\mathrm{A} \beta$ plaques by hydrogen bonding. Consequently, curcumin can be considered as potent candidate for binding and locating $\mathrm{A} \beta$ plaques in a brain suffering from $\mathrm{AD}$ [32]. Besides, in vivo studies have documented that curcumin inhibits the aggregation of $A \beta$ and also reduces the size of deposits [33,34]. Curcumin destabilizes $A \beta 40$ and $A \beta 42$ [35] as well as pyrazoles and isoxazoles (derived from curcumin) upon binding with $A \beta$ inhibits the metabolism of A $\beta P P$ [36]. Curcumin also has the potential to block $A \beta$ self-assembly by inhibiting $A \beta$ formation [33]. Kim et al. [37] stated that curcumin protects human umbilical endothelial cells and PC12 cells (PC12 cell line is used in neuroscience research, such as studies on neuroprotection, neurotoxicity, and neuroinflammation [38]) from oxidative stress-induced by $A \beta$ that helps to suppress the levels of oxidized proteins and interleukin$1 \beta$ in the brains of APP mice. Fiala et al. [39] proposed that bone marrow-derived dendritic cells may correct immune defects and offer immunotherapy to the person suffering from $\mathrm{AD}$ by enhancing the $\mathrm{A} \beta$ uptake by macrophages. Curcumin regulates $\mathrm{A} \beta$ metabolism and inhibits $A \beta$ aggregation in several ways, as shown in Figure 1.

Yang et al. [33] reported that curcumin reduced the aggregation of $A \beta$ oligomers in vitro. Tetrahydrocurcumin, a metabolite of curcumin, increased the levels of ROS, decrease mitochondrial membrane potential, and protects human neurons from oligomeric $A \beta$ induced toxicity [40]. On the other hand, a study conducted by Arjun et al. [41] claimed that curcumin did not hinder $A \beta$ fibril formation, but relatively enhance the population of "off-pathways" pre-fibrillar aggregates and soluble oligomers that were non-toxic. They also stated that curcumin reduced the toxicities instigated by $\mathrm{A} \beta$ conformers such as fibrillar, pre-fibrillar, monomeric, and oligomeric $A \beta$ and exhibited a non-specific neuroprotective impact. Moreover, the neuroprotective effect of curcumin might be membrane-mediated as it suppresses the cell membrane permeability instigated by $A \beta$ aggregates. So, their findings suggest two pathways for curcumin's neuroprotective ability (1) modification of $A \beta$ aggregates towards the development of non-toxic aggregates, (2) amelioration of $A \beta$-instigated toxicity via non-specific pathways.

\subsection{Curcumin and Glial Cells}

Glial cells are non-neuronal cells (consisting of astrocytes, oligodendrocyte lineage cells as their significant components and especially microglia) from the immune system of the central nervous system (CNS) play major roles in modulating neural plasticity, maintaining homeostasis, and shaping brain development [42]. Microglia, being the primary immune cell of the CNS and due to highly responsive cell, reacts immediately against local injury, a multiplicity of brain pathologies, neuroinflammation, and immune surveillance [43]. Recently conducted studies on genetics have highlighted more about 
the importance of these cells as with the discovery of many polymorphisms in microglialenriched genes. They are related to various neurological disorders such as amyotrophic lateral sclerosis, frontotemporal dementia, AD, schizophrenia, and autism [42]. Glial cells originate an inflammatory cascade under the influence of nuclear factor kappa-light-chainenhancer of activated B cells (NF- $\mathrm{KB}$ ) signaling. NF- $\mathrm{KB}$ seems to modulate the expression of many chemokines and cytokines, including interleukin, tumor, interferon, necrosis factor $\alpha$, and inflammation reactive proteins. These proteins and cytokines through paracrine or autocrine pathways excite the glial cells for additional production of $\mathrm{A} \beta 42$, $\mathrm{p}$-tau, and pro-inflammatory molecules that causing neurodegeneration (Figure 2).



Figure 1. Anti-amyloid properties of curcumin. Curcumin regulates $A \beta$ metabolism and inhibits $A \beta$ aggregation in several ways.

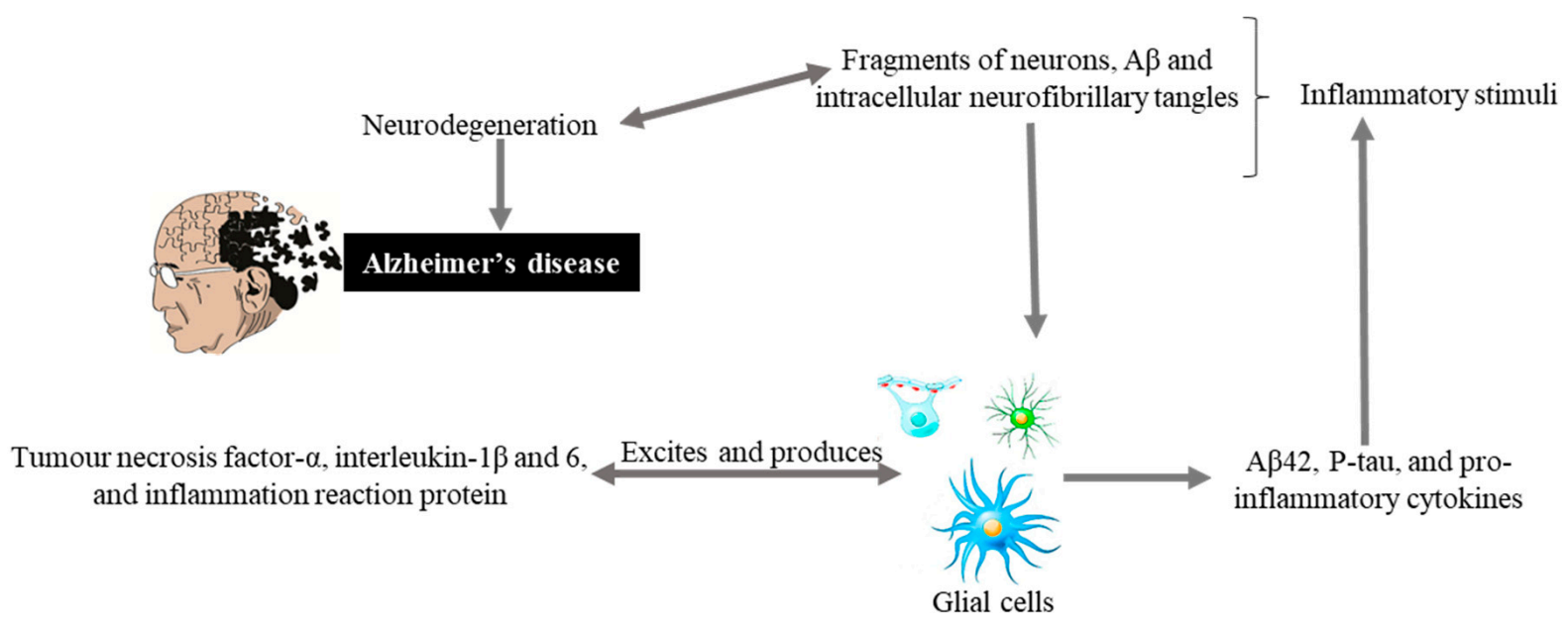

Figure 2. Hypothetical inflammation in AD. Inflammatory stimuli activate glial cells that produce tumor necrosis factor- $\alpha$, interleukin- $1 \beta$ and 6 , and inflammation reaction proteins. These can also excite glial cells that produce A $\beta 42, \mathrm{P}$-tau, and pro-inflammatory cytokines, and cycle is maintained that leads to neurodegeneration and Alzheimer's disease.

Concerning this, many studies have reported that through inhibiting activation of the TLR4/MyD88/NF- $\mathrm{KB}$ signaling pathway and promoting M2 polarization, curcumin offers protection of neurons [44]. Liu et al. [45] documented that curcumin enhances the PPAR $\gamma$ activity and reduces the production of cytokines, astrocytes, and microglia through the inhibition of the NF- $\mathrm{KB}$ signaling that decreases the neuroinflammation in AD induced rats. Curcumin could regulate the production of CC motif ligand 2 and reduce c-Jun $\mathrm{N}$-terminal kinase phosphorylation in astrocytoma cells [46]. Additionally, curcumin has 
the ability to enhance the RANTES (Regulated upon Activation, Normal T Cell Expressed and Presumably Secreted) expression in P1-3K signaling pathways, activated mitogenactivated protein kinase (MAPK), and in astrocytes so, ultimately shows neuroprotective activities in rats [47]. Tai et al. [48] exhibited that curcuminoid submicron particles can improve the pathological deficits and memory impairment in mouse with AD. Moreover, it decreases the astrogliosis and $\mathrm{A} \beta$ plaques in vivo and enhances the microglial $\mathrm{A} \beta$ phagocytosis in vitro. Thus, these are the main mechanisms that shows the beneficial properties of curcuminoid submicron particles in modulation of neuroinflammation. Curcumin at $160 \mathrm{ppm}$ can reduce oxidative damage, significantly reduce $A \beta$ and can inhibit markers of glial inflammation such as cytokine interleukin-1 and glial fibrillary acidic protein in AD transgenic mice [49]. Hence, curcumin has low toxicity and high efficacy, so can be a potential agent for $\mathrm{AD}$ treatment.

\subsection{Curcumin and Tau Proteins}

Tau proteins are associated with microtubules (major components of the cytoskeleton and abundantly present in neurons), found in the central and peripheral nervous system. Post-translational modifications (most notable phosphorylation) are deciding the localization of tau in neurons [50]. Same as other proteins associated with microtubule, tau also monitors intracellular trafficking and stabilizes microtubule integrity [51]. Conversely, in $\mathrm{AD}$, tau losses their normal functioning to bind microtubules but start to bind each other's which results in accumulated phosphorylation. Due to phosphorylated tau overall tubulin assembly starting to decrease that lead towards the development/formation of intraneuronal NFTs [52]. These NFTs remain intracellular and causing the death of neurons [53]. Moreover, impaired tau's function increases the burden on the mitochondrial function that leads to ROS release and mitochondrial dysfunction [54]. Thus, therapeutic agents that can target tau pathology, not only repair abnormality in tau but also restrain a series of reactions caused by the abnormality of tau could play a vital role in the treatment of AD [55]. Studies have been confirmed that curcumin has these abilities that could decrease hyperphosphorylated tau aggregation and restrain tau hyperphosphorylation [56] by avoiding intracellular fibrillary tangles [57,58]. Curcumin can suppress tau protein dimmer formation and hyperphosphorylated tau protein oligomerization and prevents glycogen synthase kinase-3 $\beta$ activity in tau protein-induced AD mice. However, docosahexaenoic acid and curcumin (oral administration) inhibited insulin receptor substrate 1 and c-Jun $\mathrm{N}$-terminal kinase (family of protein kinases that have a significant role in stress signaling pathways associated with neuronal plasticity, cell death, gene expression, and regulation of cellular senescence [59]) activities that suppressed hyperphophorylated tau protein levels [60]. Another mechanism of hyperphosphorylation inhibition by curcumin is reported by Huang et al. [61] which showed that human neuroblastoma SHSY5Y cells via the phosphate and tensin homologue/protein kinase B (Akt)/GSK-3 pathway which is induced by $A \beta$ inhibits the tau pathologies.

\subsection{Curcumin, Oxidative Stress and Metal Chelation}

It has been reported that oxidative stress plays a vital role in the pathogenesis of neurological and age-related diseases. Activation of nuclear factor erythroid 2-related factor 2 (Nrf2) occurs during oxidative stress that modulates the expression of various antioxidant dense enzymes and exhibits protective effects for free radical-mediated neuronal damage [62]. Further, Nrf2 also regulate genes related to nerve growth factor signaling and autophagy [63]. Several lines of evidence have demonstrated activation of the Nrf2 pathway as a promising novel strategy for the management and prevention of diseases related to the brain. Curcumin through its antioxidant effect raises the levels of glutathione that suppresses formation of 3-nitrotyrosine (indicator of nitric oxide production, inflammation, and neural damage) [64]. Gao et al. [65] demonstrated curcumin loaded T807/triphenylphosphine-red blood cell nanoparticles in AD model mice and found relieved symptoms of $\mathrm{AD}$ by mitigating mitochondrial oxidative stress and 
neural death in vitro and in vivo. Curcumin exhibits metal chelation properties that are due to its two methoxyphenol groups linked with a $\beta$ di-ketone linker, which helps in scavenging hydroxyl radicals preserve glutathione and superoxide that ultimately suppresses oxidative damage. Additionally, it is also a selective activator of Nrf2/Keap1/ARE, which trigger heme oxygenase-1 (a redox-sensitive inducible protein) and relieves oxidative stress-mediated neuronal injury [66]. As well, curcumin shields astrocytes (as activation of astrocytes is one of the key pathological hallmarks of neural disorders) from oxidative stress and mitochondria impairment. It has a defensive action on astrocytes by its negative consequence on apoptosis and reactive astrogliosis [67]. It has been documented that curcumin prevents astrogliosis in astrocytes, mitochondrial dysfunction, and caspase 1-dependent inflammation that ultimately hampers the mitochondria-dependent/independent apoptosis caused by oxidative damage [68]. Maiti et al. [69] observed that relative to natural curcumin, solid lipid curcumin particles were more permeable, useful on $A \beta$ plaques and produced a more considerable decrease of pyknotic or tangle-like, neurons in the prefrontal cortex, CA1, and CA3 areas of the hippocampus.

\section{Limitations with Chemical Properties}

Administration of curcumin can exhibit neuroprotective effects but due to blood-brain barrier (interaction with specific efflux transporters) or due to the presence of hydroxyl group, $\beta$-diketone moiety, and active methylene group in its structure, and its lipophilic nature show low pharmacokinetics/bioavailability [70,71]. The existence of hydroxyl groups in curcumin's structure make it to metabolize by the kidney and liver enzymes rapidly; that's why indicates poor absorption. Additionally, curcumin is very unstable in most body fluids like water, so, it is recommended to mix with milk or oil before consumption to increase absorption and metabolism. Thus, these properties making its use limited, leading to a challenge for the disease treatment in in vivo studies as a neuroprotective agent. Hence new formulations of curcumin are urgently needed, mainly to increase curcumin's solubility for AD treatment. Recently, several researchers have been reported that, combining curcumin with other bioactive compounds could be useful against the treatment of AD. Lin et al. [72] combined curcumin and berberine treatment and found significant results (synergistically). They reported reduced soluble $\mathrm{A} \beta_{(1-42)}$ peptide production, oxidative stress and inflammatory responses in both the hippocampus and cortex of AD mice. Furthermore, Alamro et al. [73] studied the effect of curcumin and vitamin D3 on primary cortical neuronal cultures exposed to $A \beta_{1-42}$ toxicity. Experimental treatments with $A \beta$ peptide (1-42) showed an increase in lipid peroxidation products in the existence of curcumin and vitamin $\mathrm{D}_{3}$. Biochemical assays for oxidative stress including glutathione, lipid peroxidation, catalase, superoxide dismutase and glutathione S-transferase were raised significantly in the presence of vitamin $\mathrm{D}_{3}$ and curcumin. This study exhibited that curcumin and vitamin $\mathrm{D}_{3}$ treatment showed better recovery of neuronal cells. Moreover, the upregulation of neurotrophic growth factor levels was also observed.

\section{Curcumin, Gut Microbiota and AD}

Although $\mathrm{AD}$ is a neurodegenerative disease, however, scientists are considering a new hypothesis that despite the limited bioavailability of curcumin in gut, it has an indirect influence on the CNS that is due to microbiota-gut-brain axis [74]. It has been stated that gut bacterial metabolites employ their neuroprotective effects in several neurodegenerative disorders like AD [74-76]. Microbiota-gut-brain axis is a complex but bidirectional system in which gut microbiota (GM) and its composition represent a factor that preserves and determines the brain health $[77,78]$. Recently Sun et al. [79] revealed that the interaction between curcumin and GM is bidirectional as GM transform curcumin while curcumin influences on the abundance of GM. It has been found that administration of curcumin tends to enhance the spatial learning and memory abilities as well as inhibits the $A \beta$ plaques in the hippocampus of APP/PS1 mice. Apart from this, curcumin significantly alters the composition of GM taxa such as Prevotellaceae, Bacteroidaceae, Lactobacillaceae, and Rikenellaceae 
at family level Bacteroides, Prevotella, and Parabacteroides at the genus level, several of them are considered to be associated with AD development [79]. While the GM metabolite curcumin through demethylation, reduction, acetylation, hydroxylation, and demethoxylation [80]. The produced metabolites have been documented to show neuroprotective effects in AD-induced mice [79] (Figure 3). It has been considered that gut metabolism can indirectly pose neuroprotective abilities via modulation of gut-brain axis (GBX) $[75,81]$. These findings not only enlighten the paradox between the low bioavailability of curcumin and its pharmacological effects, but also claim that GM might act as a useful source for microbiome-targeting therapies for AD. The low oral bioavailability of curcumin may be speculated as a plausible factor that limits its effects in humans [68]. Thus, utilization of several approaches can improve the bioavailability and its therapeutics as Annunziata et al. [82] proposed that fermentation is a natural strategy with minimum environmental impacts to increase the bioavailability of bioactive compounds (e.g., curcumin) that may help to cope up with AD. Fermentation mainly enhances the solubility and converts it to activated form that the body readily utilizes it for proper therapeutic effects. There are different types of fermentation (including lactic acid fermentation, alcohol fermentation, and acid fermentation), among them lactic acid fermentation considered as better because it is not contributing to cytotoxicity [83]. On the other hand, microencapsulation is a new strategy to improve the availability, delivery and therapeutic effects [84]. In microencapsulation, substances are incorporated in microscopic capsules that can measure from millimeter to micrometer, consist continuous films of coating material [85]. Microencapsulation enhances the solubility of curcumin in the aqueous solution and protect it during the gastrointestinal tract interact as well as increase the residence of curcumin and other substances in the intestine with the promotion of endocytosis [86]. Besides, Reddy et al. [75] suggested that nanoencapsulation is the encapsulation of substances at the nanoscale, improves the solubility, stability, target specificity, and drug release of the substance. It is considered advantageous as compared to microencapsulation as they have ultrathin layers that improve mass transport of substances to the islets and also reduces the volume of material [87]. Positive effects of these approaches in cell and animal models have shown positive results, but studies related to human are still lacking.

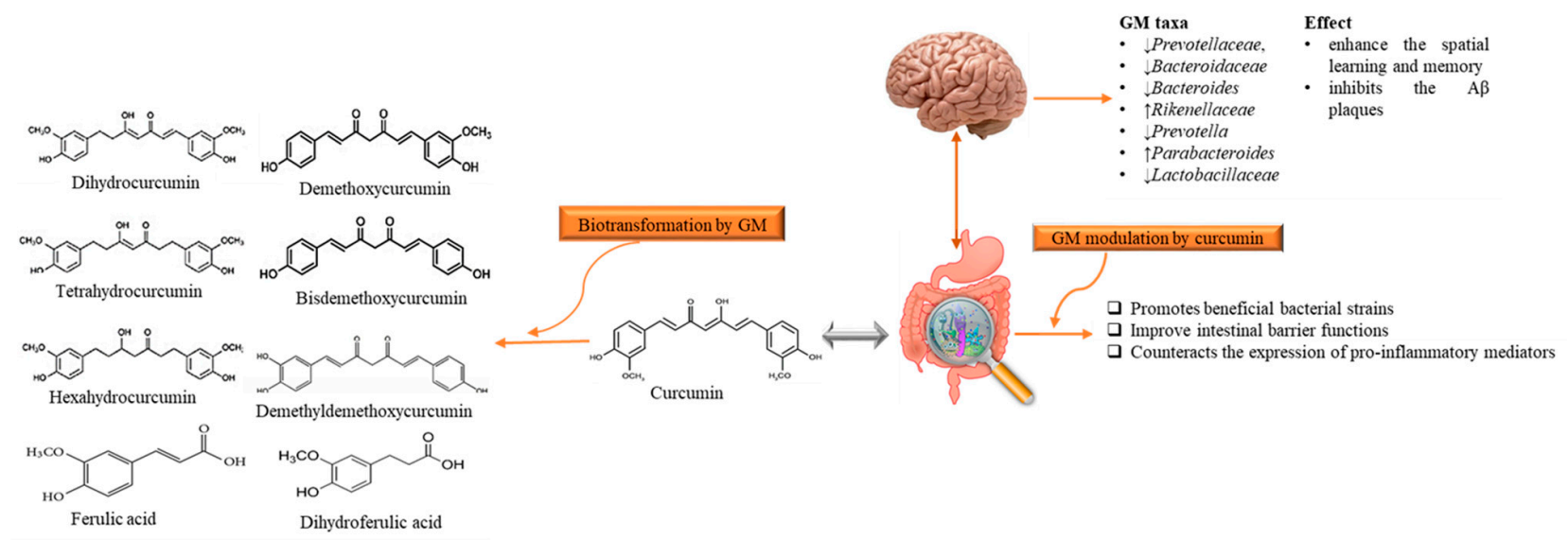

Figure 3. The reciprocal interaction between curcumin and Gut microbiota. Biotransformation of curcumin occurs due to gut microbiota that converts it into several metabolites through pathways like demethylation, reduction, acetylation, hydroxylation, and demethoxylation. These metabolites through gut-brain axis show antioxidant, anti-inflammatory, and neuroprotective effects. While, gut microbiota modulation alters the microbial abundance, diversity and composition, which also exert health benefits in Alzheimer disease-induced rats, indirectly. GM: gut microbiota.

\section{Curcumin Derivatives}

To overcome the bioavailability issues, curcumin-based compounds have been synthesized. Designing and synthesis of novel compounds have shown a better pharmacoki- 
netic profile, target selectivity, water solubility, and stability. Structural modification of molecules (e.g., curcumin) reduce the molecular size or increase the lipophilicity; the bloodbrain barrier penetration can be enhanced by focusing on reducing the efflux transport, through improving the transcellular diffusion permeability [88]. Curcumin derivatives have shown the increased anti-neuroinflammation, anti-amyloidogenic, antioxidative, and tau formation inhibitory activities as compared to natural curcumin [89]. Modifications also amplify the mitochondrial-protective effects. Similarly, curcumin pyrazole derivatives (e.g., C1-C6 and CNB-001) have exhibited more defensive properties on mitochondrial dysfunction, and its related abnormalities by enhancing nuclear translocation of Nrf2, attenuating intracellular ROS, and inhibiting the $\Delta \Psi \mathrm{m}$ (mitochondrial membrane potential) loss [90]. It has been documented that micelles of curcumin are beneficial in inhibiting oxidative stress and mitochondrial swelling than natural curcumin [91].

Further, the hybridization of different compounds with curcumin is another approach to combat its imperfection. It has been revealed that melatonin and curcumin hybridization can ameliorate the curcumin bioavailability, its functionality and can pass the blood-brain barrier. Thus, hybridization could be promising and significant approach in neuroprotective therapy $[92,93]$. In addition, bioconjugates of curcumin like di-glutamoyl esters, di-valinoyl, and di-demethylenated piperoyl enhance neuroprotective effects against mitochondrial dysfunction, damage and nitrosative stress [94]. Many studies have been conducted to modify curcumin's structure to analyze their activity against AD and other neuro-related diseases. Curcumin derivatives, those have been confirmed to cross the blood-brain barrier and showed activity against AD hall markers are documented in Table 1 . These studies have provided important details about the design and synthesis of curcumin and its derivatives.

Table 1. Modified curcumin's structure and their possible role against Alzheimer's disease.

\begin{tabular}{|c|c|c|c|}
\hline Modification of Curcumin & Neuroprotective Action & Study & References \\
\hline Diketone replaced with pyrazole & Act as inhibitor against $A \beta$ aggregation & In vitro and In vivo & [95] \\
\hline $\begin{array}{l}\text { Two aromatic rings connected by a } \\
\text { nitrogen-containing bridge }\end{array}$ & Hinder extracellular amyloid toxicity & $\begin{array}{c}\text { In vivo (rat } \\
\text { hippocampal neurons) }\end{array}$ & [96] \\
\hline $\begin{array}{c}\text { Substituted derivatives of } \\
\text { Dimethylaminomethyl (which have a large } \\
\text { steric hindrance), to the ortho position of the } \\
\text { hydroxy groups }\end{array}$ & Block the self-aggregation of $A \beta$ & In vitro & [97] \\
\hline Enol form of the compound & Significantly attenuation of the cell & & \\
\hline $\begin{array}{l}\text { Methoxycarbonylethyl group at the } \\
\text { C- } 4 \text { position }\end{array}$ & $\begin{array}{c}\text { toxicity of } A \beta \\
\text { High affinity for } A \beta \text { aggregation }\end{array}$ & In vitro and In vivo & [98] \\
\hline Demethoxycurcumin & $\begin{array}{l}\text { Effect on } A \beta \text { precursor protein through } \\
\text { the internal ribosome entry sites }\end{array}$ & In vitro & [99] \\
\hline $\begin{array}{c}\text { At least one enone group in the spacer between } \\
\text { aryl rings and an unsaturated carbon spacer } \\
\text { between aryl rings. Methoxyl and hydroxyl } \\
\text { substitutions in the meta and para-positions on } \\
\text { the aryl rings }\end{array}$ & Act as inhibitor against $A \beta$ aggregation & In vitro and In vivo & [100] \\
\hline Monogalactose group & Inhibit $\mathrm{A} \beta$ peptide aggregation & In vitro & [101] \\
\hline Contain more hydrophilic hydroxyl groups & Upregulate Neprilysin & In vitro and In vivo & [102] \\
\hline $\begin{array}{c}\text { Side aryl rings: 4-Hydroxy-3-methoxyphenyl } \\
\text { as A ring and 4-Benzyloxyphenyl or para-tolyl } \\
\text { as B ring }\end{array}$ & Inhibit $\beta$-secretase & In vitro docking & [103] \\
\hline Half side of curcumin's structure & $\begin{array}{c}\text { Protect against } A \beta \text { toxicity through } \\
\text { nematode ortholog of Nrf2 }\end{array}$ & In vitro & [104] \\
\hline $\begin{array}{l}\text { Gd(III)(diethylenetriaminepentaacetate) and } \\
\text { tert-butyl (2-propionamidoethyl)carbamate }\end{array}$ & $\begin{array}{c}\text { Redirect metaltriggered } \\
\mathrm{A} \beta \text { aggregation }\end{array}$ & In vitro & [105] \\
\hline
\end{tabular}


Table 1. Cont.

\begin{tabular}{|c|c|c|c|}
\hline Modification of Curcumin & Neuroprotective Action & Study & References \\
\hline 4-Hydroxyl group & Protect from $A \beta$ proteins $\left(A \beta_{1-42}\right)$ & In vitro & [106] \\
\hline Hydroxyl group & Block the self-aggregation of $A \beta$ & In vitro & [107] \\
\hline $\begin{array}{l}\text { 4,6-Bis((E)-4-(1H-imidazol-1-yl)styryl)-2,2- } \\
\text { difluoro-2H-1,3,2-dioxaborinin-1-ium-2-uide }\end{array}$ & $\begin{array}{c}\text { Lowers A } \beta \text { levels in conditioned media } \\
\text { and reduces oligomeric amyloid levels } \\
\text { in the cells, Attenuates the maturation } \\
\text { of APP in the secretory pathway, } \\
\text { Inhibits } \beta \text {-secretase }\end{array}$ & In vitro and In vivo & [108] \\
\hline Feruloyl-donepezil hybrid & $\begin{array}{l}\text { Ability to modify the kinetics of } A \beta \\
\text { fibril formation }\end{array}$ & $\begin{array}{l}\text { In vitro } \\
\text { In vivo }\end{array}$ & [109] \\
\hline TML-6 & $\begin{array}{c}\text { Inhibit the synthesis of the APP and } \\
\mathrm{A} \beta \text {, upregulate Apo E, suppress NF- } \mathrm{B} B \\
\text { and mTOR, and increase the activity of } \\
\text { the antioxidative Nrf2 gene }\end{array}$ & In vivo & [110] \\
\hline
\end{tabular}

A $\beta$ : amyloid-beta, Nrf2: nuclear factor erythroid 2-related factor 2, APP: amyloid precursor protein.

\section{Blood-Brain Barrier and Drug Delivery}

The blood-brain barrier is a highly selective semipermeable border of endothelial cells that is a border against circulating foreign substances from non-selectively crossing into the extracellular fluid of the brain. It is a hurdle against the delivery of therapeutic or diagnostic agents to the neurons residing in the brain [111]. Multiple ways have been reported for bio-macromolecules and small molecules to penetrate through the blood-brain barrier [112]. These pathways are generally driven by the concentration gradient of the substrates with the assistance of suitable transporters [113]. There are different ways to pass through the blood-brain barrier for small molecules so they can spread into the brain parenchyma (functional tissue, made up of neurons and glial cells) under physiological conditions (Figure 4) but dependent on their characteristics [113]. (1) for small hydrophilic molecules, paracellular transportation through an aqueous pathway is specific. It can transfer substances across the epithelium by passing through the intercellular space between the cells [112]. (2) the transcellular diffusion of small lipophilic molecules, those reach to the brain tissues through a non-saturable mechanism [114]. A certain amount of lipophilic drugs with molecular weight less than $500 \mathrm{Da}$ can penetrate through the blood-brain barrier. In contrast to diffusion through the hydrophilic membrane, diffusion through lipophilic membranes is strongly dependent on the correlating features of surface area, molecular weight, and molecular volume of a substance [115]. (3) the carrier-mediated pathway, endogenous transporter or substrate-specific process in which the remaining small molecules reach to the brain [116], substances pass through the basolateral membrane and apical membrane. In the carrier-mediated pathway, proteins (ATP-binding cassette, glucose carrier, and LT1) are used to transport hydrophilic molecules through facilitated diffusion or active transport [117]. (4) the receptor-mediated transportation uses the vesicular trafficking of brain endothelial cells to transport some types of protein like leptin, insulin, lipoproteins, and transferrin [118]. D'Souza [117] recommended receptor-mediated endocytosis for the delivery of the targeted drug. Binding of ligands to the receptors triggers the internalization in receptor-mediated endocytosis. Thus, nanoformulations composed of ligands can transport across the membrane [119]. (5) Endothelial cells have negatively charged plasma membranes, positively charged molecules bind with membranes and cross blood-brain barrier by adsorptive-mediated endocytosis [120]. Majority of substances penetrate the brain through the carrier-mediated pathway, receptor-mediated pathway, and adsorptive-mediated pathway as structures of molecule possesses high affinity for a particular receptor, charged membranes or carrier found in blood-brain barrier [121]. 


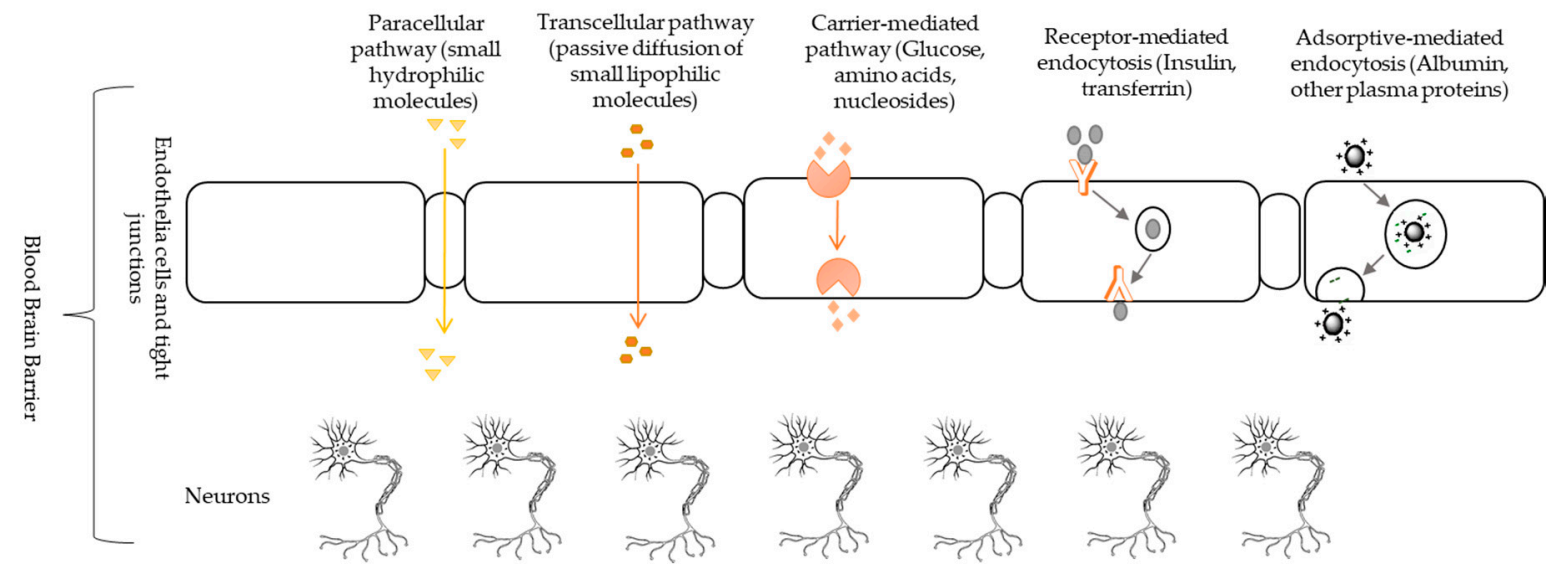

Figure 4. Main pathways for nanoparticles to cross the blood-brain barrier. Penetration of charged molecules (including cationic nanoparticles: liposomes and gold nanoparticles) depends on adsorptive-mediated endocytosis while molecules with high hydrophilicity (like transferrin conjugated nanoparticles, liposomes, poly(lactic-co-glycolic acid/poly (lactic acid)) needs receptor-mediated endocytosis. Carrier-mediated pathway is a substrate-specific process while small hydrophilic molecules penetrate through paracellular pathway. Passive diffusion of small lipophilic molecules, e.g., gold nanoparticles occur through transcellular pathway.

Molecular Trojan horses and nanomedicines are the emerging and novel strategies used for the drug-delivery through the blood-brain barrier [122]. The specific properties of nanomaterials like prolonged blood circulation, non-toxicity, biocompatibility, and reduced size have been exploited for the creation/development of evolving delivery platforms that can facilitate the passage of therapeutic/diagnostic drugs to the brain [123].

\section{Nanoformulations and Their Role in AD}

In recent years, nanotechnology-based drug delivery systems have gained substantial attention because of their promising potential to prolong the residence and circulation of drugs in the blood and also enhance the drug's aqueous stability and solubility. In addition, enhances the ability of drugs to cross the physiological barriers, that results in the enhancement of bioavailability [124].

\subsection{Nanoparticles/Nanosensors as Theranostic Agents}

Detection of AD during the early stages or the phase of the illness will offer great relief to patients suffering from AD, their friend and families, along with the economy [125]. Thus, it is the need of time to create multi-mode devices capable of simultaneous monitoring of many biomarkers that can stimulate fast, low cost, and reliable diagnosis [126]. Neurotransmitters are suitable biomarkers for various neurological disorders, such as AD. Several analytical techniques, such as microdialysis, capillary electrophoresis and electrochemistry are generally used to diagnose neurotransmitters of AD. However, researchers are still striving to discover an easy and accurate method to detect neurotransmitters of $\mathrm{AD}$ before devastating symptoms begin. In the last decade, biosensors have gained popularity as an attractive alternative method, and valuable efforts have been successfully made by scientists for the development of viable biosensors to propose a new analytical platform [127]. Biosensors are devices used for the detection of a chemical substance. They integrate a biochemical binding component with a signal conversion part and recently, several researchers have investigated the use of unique materials for developing biosensor for detection of different biomarkers of $\mathrm{AD}[128,129]$. With the advancement in nanotechnology, nano-bio sensors have many prospective benefits as compared to other analytical or clinical methods. This advancement leads to improved assay efficiency, decrease in diagnostic testing costs, resourcefulness, and ability to deliver family general practitioners with molecular diagnostic devices [130]. Furthermore, the incorporation with nanocarriers has also been documented to enhance the conductivity and catalytic properties of the 
transducer. It happens while facilitating the immobilization of a large number of biological recognition elements because of the large surface area of nanoparticles [131]. The most common nanoparticle formulations that have a significant impact in the diagnosis and therapy of AD include polymeric nanoparticles, protein-based nanoparticle, gold nanoparticle, polysaccharide-based nanoparticle, selenium nanoparticle, gadolinium nanoparticle, etc. [132]. Recently, carbon nanomaterials, including carbon nanostructures, carbon dots, carbon nanotubes, graphite, graphene, and fullerene have received considerable significance [133]. After crossing the blood-brain barrier, nanoparticles can bind monomers and oligomers of $A \beta$ so, specific inhibition of neurotoxicants can help to ameliorate AD. Surface functionalization or chemical modification of these nanocarriers may improve the aqueous solubility, and therefore, facilitating their utilization to treat the neurodegenerative disorders. Moreover, the concentration of drugs or conjugation of drugs with nanocarriers can be considerably used as an effective neuro-drug delivery system [134]. Mostly used nanomaterials that can penetrate through the blood-brain barrier and have diagnostic/therapeutic values are depicted in Table 2.

Table 2. Different types of nanoformulations/biosensors in the diagnosis/therapy of AD.

\begin{tabular}{|c|c|c|c|c|c|}
\hline Nanostructure & Diameter & Application & Role in AD & Study & References \\
\hline \multirow[b]{2}{*}{ Thioflavin-T } & \multirow[b]{2}{*}{ 250-300 nm } & Diagnostic & Identify $A \beta$ in senile plaques & $\begin{array}{l}\text { in vitro and } \\
\text { In vivo rats } \\
\text { and mice }\end{array}$ & {$[135,136]$} \\
\hline & & Therapeutic & $\begin{array}{c}\text { Inhibit } \mathrm{A} \beta_{42} \text { fibrillogenesis and } \\
\text { disaggregate amyloid fibrils } \\
\text { Exhibit cytoprotective effects against } \\
\mathrm{A} \beta 42 \text { fibrillation-induced cytotoxicity }\end{array}$ & $\begin{array}{l}\text { In vitro and } \\
\text { In vivo }\end{array}$ & [137] \\
\hline \multirow[b]{2}{*}{ Gold } & \multirow[b]{2}{*}{$40-50 \mathrm{~nm}$} & Diagnostic & $\begin{array}{l}\text { Targeted finding of tau protein in } \\
\text { cerebrospinal fluid recognise the } \\
\text { A } \beta \text { complexes }\end{array}$ & In vitro & {$[138,139]$} \\
\hline & & Therapeutic & $\begin{array}{c}\text { Inhibition of } A \beta \text { aggregation, dissociate } \\
A \beta \text { fibrils } \\
\text { Decrease } A \beta \text {-mediated peroxidase } \\
\text { activity and } A \beta \text {-induced cytotoxicity, } \\
\text { acquisition and retention of spatial } \\
\text { learning and memory }\end{array}$ & In vivo rats & {$[140,141]$} \\
\hline \multirow[b]{2}{*}{ Liposome } & \multirow[b]{2}{*}{$100-210 \mathrm{~nm}$} & Diagnostic & Target of amyloid plaques & In vitro & [142] \\
\hline & & Therapeutic & $\begin{array}{l}\text { Inhibit the apoptosis of } A \beta_{1-42} \\
\text { decrease lipid peroxidation level, } \\
\text { acetylcholinesterase activity } \\
\text { Prevents } A \beta \text { plaque formation }\end{array}$ & $\begin{array}{l}\text { In vitro and } \\
\text { In vivo rats }\end{array}$ & [143] \\
\hline \multirow[b]{2}{*}{$\begin{array}{l}\text { Polymeric based } \\
\text { (natural and } \\
\text { synthetic) }\end{array}$} & \multirow[b]{2}{*}{$40-500 \mathrm{~nm}$} & Diagnostic & Identify $A \beta$ and tau protein & $\begin{array}{l}\text { In vitro and } \\
\text { In vivo }\end{array}$ & [132] \\
\hline & & Therapeutic & $\begin{array}{c}\text { Iinternalize successfully by } \\
\text { oligodendrocytes, astrocytes, microglial } \\
\text { cells, and neurons } \\
\text { Destroy senile plaques and improve the } \\
\text { memory impairment }\end{array}$ & $\begin{array}{l}\text { In vitro and } \\
\text { In vivo }\end{array}$ & {$[126,132]$} \\
\hline \multirow{2}{*}{ Carbon based } & \multirow{2}{*}{$\begin{array}{c}1 \mathrm{~nm} \text { to } 10 \mathrm{~s} \\
\text { of } \mathrm{nm}\end{array}$} & Diagnostic & $\begin{array}{c}\text { Asses phosphorylated tau protein, tau } \\
\text { protein, beta-amyloid } 40 \text {, and } \\
\text { beta-amyloid } 42\end{array}$ & $\begin{array}{l}\text { In vitro and } \\
\text { In vivo rats }\end{array}$ & [126] \\
\hline & & Therapeutic & Potential of decreasing $A \beta$ & $\begin{array}{l}\text { In vitro and } \\
\text { In vivo rats }\end{array}$ & [126] \\
\hline
\end{tabular}


Table 2. Cont.

\begin{tabular}{|c|c|c|c|c|c|}
\hline Nanostructure & Diameter & Application & Role in AD & Study & References \\
\hline Gadolinium & $2-15 \mathrm{~nm}$ & Diagnostic & $\begin{array}{l}\text { Specifically, target amyloid fibrils for } \\
\text { early detection of amyloid deposits }\end{array}$ & $\begin{array}{l}\text { In vitro and } \\
\text { In vivo mouse } \\
\text { and mice }\end{array}$ & [144] \\
\hline Quantum dots & & Diagnostic & $\begin{array}{l}\text { Identify the APP and A } \beta \text { plaque with } \\
\text { enhancing sensibility compared with } \\
\text { traditional fluoro immune assay }\end{array}$ & In vivo mice & [145] \\
\hline Selenium & $<200 \mathrm{~nm}$ & Therapeutic & $\begin{array}{l}\text { Decrease } \mathrm{A} \beta \text { plaques aggregation and } \\
\text { decrease inflammations, } \\
\text { Displays no deceptive abnormalities in } \\
\text { histopathological images In vivo }\end{array}$ & $\begin{array}{l}\text { In vitro and } \\
\text { In vivo }\end{array}$ & [32] \\
\hline Iron chelators & $10-20 \mathrm{~nm}$ & Therapeutic & $\begin{array}{l}\text { Detection of AD in early stages. } \\
\text { Elevated brain iron is associated with } \\
\text { cognitive decline. Conservative } \\
\text { iron chelation with a high blood-brain } \\
\text { barrier penetrant drug may slow the } \\
\text { rate of neurodegeneration }\end{array}$ & $\begin{array}{l}\text { In vitro and } \\
\text { In vivo }\end{array}$ & {$[146,147]$} \\
\hline Cerium & $<50 \mathrm{~nm}$ & Therapeutic & $\begin{array}{l}\text { Reduce the aggregation of } A \beta \text {, inhibit } \\
\text { the formation of } \alpha \text {-syn amyloid fibrils- } \\
\text { associated cytotoxicity and reduce the } \\
\text { oxidative stress }\end{array}$ & $\begin{array}{l}\text { In vitro and } \\
\text { In vivo }\end{array}$ & [148] \\
\hline
\end{tabular}

A $\beta$ : amyloid-beta, AD: Alzheimer's disease, APP: amyloid precursor protein.

\subsection{Curcumin Loaded with Nanoformulations and Their Therapeutic Effects in $A D$}

Nano-delivery systems such as polymeric nanoparticles, peptide carriers, micelles, liposomes, cyclodextrins, conjugates, lipidic nanoparticles, emulsions, and solid dispersions have been extensively studied for improving the overall bioavailability of curcumin for enhanced brain delivery [149]. The main characteristic and transport mechanism for brain uptake and blood-brain barrier crossing of the main curcumin conjugated nanocarriers are exhibited in Table 3. Curcumin loaded with poly(lactic-co-glycolic acid; PLGA)poly(ethylene glycol) nanoparticles permeate through the impaired blood-brain barrier and diffused efficiently through the brain parenchyma. Additionally, were localized in brain regions with $\mathrm{AD}$, and exhibited a protecting impact in the injured neonatal brain [150]. Recently, a study stated the neuroprotective effect of red blood cell membrane-coated PLGA particles bearing T807 molecules attached to the red blood cell membrane surface (T807/RPCNP) loaded with curcumin. A stabilized and sustained curcumin release was observed. Synergistic effects of T807, T807/RPCNP showed effective penetration across the blood-brain barrier, and they also exhibited a high binding affinity to hyperphosphorylated tau in nerve cells where they block multiple critical pathways in tau-associated AD pathogenesis. Additionally, curcumin loaded T807/RPCNP nanoparticles could relieve $\mathrm{AD}$ symptoms by reducing phosphorylated-tau levels and inhibiting the neuronal death both in vitro and in vivo [151]. Curcumin nanoformulation by altering the surface of the PLGA polymer and encapsulation of selenium nanoparticles could decrease the $A \beta$ load and inflammations in the brains samples of AD mice and treated the memory loss of the model mice. Moreover, the histopathological images of animal tissues displayed no deceptive abnormalities [32]. Zhang et al. [152] developed hydroxypropyl$\beta$-cyclodextrin-encapsulated curcumin complexes (CUR/HP- $\beta$-CD inclusion complexes), and curcumin encapsulated chitosan-coated PLGA nanoparticles (CUR-CS-PLGA-NPs) and compared their effects through intranasal administration. CUR/HP- $\beta-C D$ inclusion complexes (in vitro) showed stability under physiological parameters and also showed a higher cellular uptake level of curcumin as compared to CUR-CS-PLGA-NPs. Further, both formulations behaved to reduce cellular cytotoxicity and exhibited antioxidant and 
anti-inflammatory effects. in vivo, after intranasal administration, the area under cover values of curcumin in the brain and plasma of the CUR/HP- $\beta-C D$ inclusion complex group also showed higher values. So, CUR/HP- $\beta$-CD inclusion complexes presented better properties for application in AD than CUR-CS-PLGA-NPs.

Recently, Yavarpour et al. [153] evaluated the neuroprotective effects of curcumin loaded lipid-core nanocapsules in a model of AD induced aged female mice. The results of this study showed that curcumin loaded lipid-core nanocapsules displayed significant neuroprotection against $A \beta 1-42$-induced behavioral and neurochemical changes in a model of AD. In another study, Sadegh et al. [154] documented the nanostructured lipid carriers with curcumin targeted the oxidative stress parameters (ADP/ATP ratio, lipid peroxidation, and ROS formation) in the hippocampal tissue resulting in improved memory conditions. Moreover, histopathological studies showed the potential of nanostructured lipid carriers with curcumin in suppressing the hallmarks of $A \beta$ in $A D$ in vitro (animal model). Sadegh et al. [155] reported another study by targeting the neuroprotective effect of nanostructured lipid carriers and solid lipid nanoparticles loaded with curcumin. This study showed that both nanoparticle techniques have higher bioavailability in the brain. They showed that 2,2-diphenyl-1-picrylhydrazyl free radical scavenging preparation processes did not exhibit any significant effect on the antioxidant activity of curcumin. Furthermore, curcumin loaded with chitosan and bovine serum albumin nanoparticles effectively enhanced the drug permeation across the blood-brain barrier, accelerated the phagocytosis of the $A \beta$ peptide and further endorsed the activation of microglia. Additionally, repressed the TLR4-MAPK/NF- $\mathrm{kB}$ signaling pathway and downregulated M1 macrophage polarization [156]. The nanomaterials discussed in this study have been demonstrated to ameliorate the availability of curcumin and can potently enhance neuronal differentiation and reverse $\mathrm{A} \beta$-induced learning and memory deficits.

Table 3. Characteristic and the transport mechanism of the main curcumin-conjugated nanocarriers for BBB.

\begin{tabular}{|c|c|c|c|c|}
\hline Nano-Carrier Type & Shape/Size & Most Investigated Components & Mechanism in BBB & References \\
\hline $\begin{array}{c}\text { Solid Lipid } \\
\text { Nanoparticles }\end{array}$ & Spherical (50-300) & $\begin{array}{l}\text { Triglycerides, monoglycerides, } \\
\text { complex glyceride mixtures, } \\
\text { hard fats, cetyl alcohol, } \\
\text { stearic acid, emulsifying wax } \\
\text { and cholesterol butyrate. } \\
\text { Surfactants are used to stabilise } \\
\text { the lipid core (about } 1-5 \% w / v \text { ) } \\
\text { or co-surfactant (such as } \\
\text { poloxamer } 188 \text { and /or } \\
\text { Tween }^{\circledR} 80 \text { ) }\end{array}$ & $\begin{array}{l}\text { Uptake by the paracellular } \\
\text { pathway through brain } \\
\text { microvasculature, } \\
\text { endocytosis and passive } \\
\text { diffusion, tight junctions } \\
\text { opening. Active targeting with } \\
\text { apolipoprotein E }\end{array}$ & {$[156,157]$} \\
\hline $\begin{array}{l}\text { Liquid Crystalline } \\
\text { Nanocarriers }\end{array}$ & $\begin{array}{l}\text { Inverted hexagonal } \\
\text { (hexosomes), } \\
\text { bicontinuous cubic } \\
\text { (cubosome), or } \\
\text { sponge phases } \\
\text { (20-200 nm) }\end{array}$ & $\begin{array}{c}\text { Unsaturated monoglycerides, } \\
\text { phospholipids, glycolipids } \\
\text { and surfactants }\end{array}$ & $\begin{array}{l}\text { Adsorption-mediated } \\
\text { transcytosis, passive targeting or } \\
\text { receptor-mediated endocytosis }\end{array}$ & {$[158,159]$} \\
\hline Liposome & $\begin{array}{l}\text { Globular/lamellar } \\
\quad(20-200 \mathrm{~nm})\end{array}$ & $\begin{array}{l}\text { Lipids: PEGylated } \\
\text { 1,2-distearoyl-sn-glycero-3- } \\
\text { phospho-ethanolamine-PEG } \\
\text { 2000, phosphatidylcholine, } \\
\text { ethyl-phosphatidyl-choline, } \\
\text { 2-dipalmitoyl-sn-glycero-3- } \\
\text { phospho-choline, lecithin, } \\
\text { sphingomyelin, cholesterol, }\end{array}$ & $\begin{array}{c}\text { Passive targeting, } \\
\text { receptor-mediated endocytosis } \\
\text { or Adsorption-mediated } \\
\text { transcytosis } \\
\text { Active targeting with receptors } \\
\text { glutathione, glucose, transferrin, } \\
\text { lactoferrin, apolipoprotein E, } \\
\text { and phosphatidic acid }\end{array}$ & {$[160,161]$} \\
\hline
\end{tabular}


Table 3. Cont.

\begin{tabular}{|c|c|c|c|c|}
\hline Nano-Carrier Type & Shape/Size & Most Investigated Components & Mechanism in BBB & References \\
\hline Micelles & Spherical (20-100 nm) & $\begin{array}{l}\text { PLGA-PEG-PLGA triblock and } \\
\text { PLGA-PEG diblock copolymers }\end{array}$ & $\begin{array}{l}\text { Uptake by endocytosis and/or } \\
\text { transcytosis. Targeting ligands } \\
\text { with surface conjugation } \\
\text { improve the transcytosis }\end{array}$ & {$[162,163]$} \\
\hline $\begin{array}{c}\text { Polymer } \\
\text { Nanoparticles }\end{array}$ & Globular (10-200 nm) & $\begin{array}{l}\text { PLGA, PBCA, PLA, } \\
\text { chitosan and alginate. }\end{array}$ & $\begin{array}{l}\text { Uptake by transcytosis and/or } \\
\text { endocytosis through the } \\
\text { endothelial cells and tight } \\
\text { junctions opening }\end{array}$ & {$[132,156]$} \\
\hline Cyclodextrins & Cyclic (150-500 nm) & $\begin{array}{c}\text { Mainly the } \\
\beta \text {-cyclodextrin derivatives }\end{array}$ & $\begin{array}{l}\text { The direct action of cyclodextrin } \\
\text { by extracting lipids like } \\
\text { phospholipids and cholesterol, } \\
\text { and proteins } \\
\text { Modify the properties of the } \\
\text { lipid bilayers and } \\
\text { molecular composition }\end{array}$ & {$[164,165]$} \\
\hline
\end{tabular}

BBB: Blood-brain barrier, PLGA: Poly (lactic-co-glycolic acid), PEG: Polyethyleneglycol, PBCA: Poly(butyl)cyanoacrylate, PLA: poly (lactic acid)

\subsection{Curcumin Derivatives, Curcumin and Its Nanoformulations Based Diagnostic Properties}

Curcumin has properties like natural fluorescence, lipophilicity, and high binding affinity to $A \beta$, making it able for early diagnostic probe/plaque labelling fluorochrome [166]. It has been documented that it fluoresces yellow/green under a violet/blue $(436 \mathrm{~nm})$ light. These natural fluorescent qualities of curcumin have been explored in many studies for diagnostic purpose, which make it to absorb light at about $420 \mathrm{~nm}$ and discharges fluorescence at around $530 \mathrm{~nm}$ in aqueous solutions [167]. During the last two decades, comprehensive research studies have been conducted to develop curcuminbased probes for targeting $A \beta$ with positron emission tomography, with existing imaging modalities, magnetic resonance imaging, near-infrared fluorescence and two-photon microscopy [168]. Si et al. [169] worked on the near-infrared fluorescence imaging probes of $\mathrm{A} \beta$ plaques for the early diagnosis of $\mathrm{AD}$. Curcumin derivative dyes showed a considerably significant improvement in its fluorescence intensity after binding to $\mathrm{A} \beta$ plaques. Furthermore, in vitro and in vivo fluorescence imaging of $A \beta$ plaques strained with one of the dyes exhibited that the compound was a potential probe to detect $A \beta$ plaques in AD. Chibhabha et al. [170] developed anionic and water-soluble DSPE-PEG2000 curcumin polymeric micelles (also referred as curcumin micelles) those can detect both brain and retinal A $\beta$ plaques. Another study showed that the curcumin-Ni electrode reported high sensitivity and wide detection range from 0.001 to $10 \mathrm{nM} \mathrm{A} \beta$ oligomer. This electropolymerized curcumin pledge the detection of $A \beta$ oligomer at lower concentration and therefore, can be a prospective tool for the early detection of AD [31]. Singh et al. [171] proposed curcumin encapsulated Pluronic F127 nanoparticles (FCur NPs) and compared their blood-brain barrier penetration of free curcumin and FCur NPs. The FCur NPs displayed 6.5-fold more potent fluoresce intensity in the brain of mice than free curcumin. Future, in vitro comparison with Congo red revealed that encapsulated curcumin maintains its ability to bind to $A \beta$ plaques. FCur NPs also exhibited antioxidant and antiapoptotic activity when compared to free curcumin. The combination of in vitro and in vivo results suggests the potential utility of the inexpensive FCur NPs as a theranostic agent for AD. Hence, it can be proposed from the mentioned studies that curcumin and its nanoformulations based techniques cannot only be used for therapeutic purpose but also for diagnostic purpose. 


\section{Safety and Limitations of Nano-Based Strategies as Theranostic Agents}

Several studies have proved the activity of nanoparticles against AD, but there are still many challenges that are concerning their application for biomedical purposes. These concerns are: (1) The short-term toxicity has been observed in many studies. (2) Most of the developed nanoparticles do not have long blood residence time that is why a large portion of them accumulate in the liver and spleen and unable to cross the blood-brain barrier. (3) To reduce the unintended adverse effects on target cells and organs, one acceptable biodegradable polymer that can increase the effectiveness of nanocarriers require. (4) Combination of nanotechnology and innovative high-tech methodologies (i.e., nano-chips or constructing implantable system/ multi-drug delivery processors) can help to strengthen drug delivery efficiency. (5) Nanoparticles those have a specific target for AD than other neurological diseases.

In diagnosis, stability and reproducibility of nanoparticles due to scalable and routine production of the bio-sensing system are also challenging. Apart from this, most studies have been conducted in artificial specimens or buffers, and real sample studies are minimal [172]. Since multiple hallmarks contributing to AD and the detection of these markers is very vital, that is still sorely missing. Thus, it is necessary to ensure a sensitive and accurate diagnosis system for the detection of those biomarkers. Some challenges are stated after. (1) need for the inclusion of one biosensor that can detect all of the pathological pathways. (2) new and improved diagnostic agents for easy, early and proper detection of AD. (3) Cost-effective techniques for early detection of hallmarks of AD.

\section{Conclusions and Perspective}

Curcumin is one of the most studied polyphenols in the spice turmeric, exhibiting complex and multifaceted activities. There has been much evidence on the protective effect of curcumin and its derivatives on the development of AD. Since AD is the most common form of dementia that occur mainly due to the formation/deposition of $\mathrm{A} \beta$ plaques and NFTs inside the nerve cells, the person suffering from AD can face many complications related to memory and brain health. Prevalence of AD posing a significant burden not only to patients but also their families due to the non-availability of an effective cure. A plethora of research work has been and is still being conducted to elucidate the complexities of AD pathology. The health-promoting effect of curcumin and its derivatives has been well documented in studies. Curcumin has shown therapeutic and diagnostic properties, but due to low bioavailability in the brain due to the blood-brain barrier, use is minimal. Therefore, curcumin-based compounds or nanoparticles have been synthesized. Designing and synthesis of curcumin-based compounds have shown a better pharmacokinetic profile and target selectivity. Additionally, nanostructured carriers have revealed the excellent encapsulating ability with improved physicochemical stability to penetrate against the blood-brain barrier. Nanocarriers as drug delivery carriers have exhibited many features such as controllable delivery, loading bioactive compounds with synergistic effects and also diagnostic properties. Although, nanoformulations conjugated with curcumin have shown many benefits against neurodegeneration but still need more to explore. In the future, nanoparticles with long blood residence time having less unintended adverse effects on target cells and organs with easy, early and proper detection are needed to be developed. Other than nanoformulations, microencapsulation also considered as a good strategy that can be used as a delivery vehicle to transport curcumin across the blood-brain barrier. Besides, due to GBX researcher are exhibiting new hypothesis that metabolites of curcumin can indirectly exhibit anti-inflammatory and antioxidative properties in AD. Taken together, current research suggests that curcumin is one of the most promising and exciting compounds for the development of AD therapeutics.

Although curcumin has multifaceted biological activity in the development of AD, however, more research needs to be done to improve the bioavailability of curcumin. Curcumin derivatives showed better bioavailability and theranostic properties as compared to natural curcumin and to increase the bioavailability of curcumin during gut 
metabolism, fermentation of curcumin before consumption can help improve the bioavailability. Microencapsulation and nanoencapsulation are also good options but nanoencapsulation showed better results in sense of solubility, stability and drug release than microencapsulation to enhance bioavailability in the context of a clinical study to treat $\mathrm{AD}$. Moreover, the development of the early diagnosis of AD and new curcumin formulations are an active area of research. If curcumin is confirmed to show the same efficacy in humans as in vitro and in vivo studies, the disease-modifying treatment of $\mathrm{AD}$ is a worthwhile possibility.

Author Contributions: U.S.: writing, original draft preparation, M.R.: revision and formatting, A.T.: revision, D.-H.O.: supervision, conceptualization. All authors have read and agreed to the published version of the manuscript.

Funding: This work was supported by a grant from the Brain Korea (BK) 21 Plus Project (Grant No. 22A20153713433) Funded by the Korean Government, Republic of Korea.

Conflicts of Interest: The authors declare no conflict of interest.

$\begin{array}{ll}\text { Abbreviations } & \\ \text { AD } & \text { Alzheimer's disease } \\ \text { APP } & \text { Amyloid precursor proteins } \\ \text { A } \beta & \text { Amyloid-beta } \\ \text { BBB } & \text { Blood-brain Barrier } \\ \text { CNS } & \text { Central nervous system } \\ \text { CUR/HP- } \beta \text {-CD inclusion } & \text { Hydroxypropyl- } \beta \text {-cyclodextrin-encapsulated curcumin } \\ \text { complexes } & \text { complexes } \\ \text { CUR-CS-PLGA-NPs } & \text { Curcumin encapsulated chitosan-coated PLGA nanoparticles } \\ \text { FCur NPs } & \text { Curcumin encapsulated Pluronic F127 nanoparticles } \\ \text { GBX } & \text { Gut-brain axis } \\ \text { GM } & \text { Gut microbiota } \\ \text { MAPK } & \text { Mitogen-activated protein kinase } \\ \text { NF- } \text { KB } & \text { Nuclear factor kappa-light-chain-enhancer of activated B cells } \\ \text { NFTs } & \text { neurofibrillary tangles } \\ \text { Nrf2 } & \text { Nuclear factor erythroid 2-related factor 2 } \\ \text { PBCA } & \text { Poly(butyl)cyanoacrylate } \\ \text { PEG } & \text { Polyethyleneglycol } \\ \text { PLA } & \text { Poly (lactic acid) } \\ \text { PLGA } & \text { Poly(lactic-co-glycolic acid) } \\ \text { ROS } & \text { Reactive oxygen species } \\ \text { WHO } & \text { World health organization } \\ & \end{array}$

\section{References}

1. Whiteford, H.A.; Ferrari, A.J.; Degenhardt, L.; Feigin, V.; Vos, T. The global burden of mental, neurological and substance use disorders: An analysis from the Global Burden of Disease Study 2010. PLoS ONE 2015, 10, e0116820. [CrossRef]

2. Andreas, S.; Schulz, H.; Volkert, J.; Dehoust, M.; Sehner, S.; Suling, A.; Ausín, B.; Canuto, A.; Crawford, M.; Da Ronch, C.; et al. Prevalence of mental disorders in elderly people: The European MentDis_ICF65+ study. Br. J. Psychiatry 2017, 210, 125-131. [CrossRef] [PubMed]

3. Chisholm, D.; Sweeny, K.; Sheehan, P.; Rasmussen, B.; Smit, F.; Cuijpers, P.; Saxena, S. Scaling-up treatment of depression and anxiety: A global return on investment analysis. Lancet Psychiatry 2016, 3, 415-424. [CrossRef]

4. Bryant, C.J.I.p. Anxiety and depression in old age: Challenges in recognition and diagnosis. Int. Psychogeriatr. 2010, 22, 511-513. [CrossRef] [PubMed]

5. World Health Organization (WHO). Dementia Fact Sheet. Available online: https://www.who.int/news-room/fact-sheets/ detail/dementia (accessed on 14 October 2020).

6. Giacomeli, R.; Izoton, J.C.; Dos Santos, R.B.; Boeira, S.P.; Jesse, C.R.; Haas, S.E. Neuroprotective effects of curcumin lipidcore nanocapsules in a model Alzheimer's disease induced by $\beta$-amyloid 1-42 peptide in aged female mice. Brain Res. 2019, 1721, 146325. [CrossRef]

7. Alzheimer's Association. Alzheimer's Disease Report. In Alzheimer's Disease Facts and Figures; Alzheimer's Association: Chicago, IL, USA, 2020. 
8. Voulgaropoulou, S.D.; van Amelsvoort, T.A.M.J.; Prickaerts, J.; Vingerhoets, C. The effect of curcumin on cognition in Alzheimer's disease and healthy aging: A systematic review of pre-clinical and clinical studies. Brain Res. 2019, 1725, 146476. [CrossRef]

9. Hefti, F.; Goure, W.F.; Jerecic, J.; Iverson, K.S.; Walicke, P.A.; Krafft, G.A. The case for soluble A $\beta$ oligomers as a drug target in Alzheimer's disease. Trends Pharmacol. Sci. 2013, 34, 261-266. [CrossRef]

10. Nortley, R.; Korte, N.; Izquierdo, P.; Hirunpattarasilp, C.; Mishra, A.; Jaunmuktane, Z.; Kyrargyri, V.; Pfeiffer, T.; Khennouf, L.; Madry, C. Amyloid $\beta$ oligomers constrict human capillaries in Alzheimer's disease via signaling to pericytes. Science 2019, 365, eaav9518. [CrossRef]

11. Fontana, I.C.; Zimmer, A.R.; Rocha, A.S.; Gosmann, G.; Souza, D.O.; Lourenco, M.V.; Ferreira, S.T.; Zimmer, E.R. Amyloid- $\beta$ oligomers in cellular models of Alzheimer's disease. J. Neurochem. 2020, 155, 348-369. [CrossRef]

12. Palop, J.J.; Mucke, L. Network abnormalities and interneuron dysfunction in Alzheimer disease. Nat. Rev. Neurosci. 2016, 17, 777-792. [CrossRef]

13. Merry, T.L.; Chan, A.; Woodhead, J.S.; Reynolds, J.C.; Kumagai, H.; Kim, S.-J.; Lee, C. Mitochondrial-derived peptides in energy metabolism. Am. J. Physiol. Endocrinol. Metab. 2020, 319, E659-E666. [CrossRef] [PubMed]

14. Agrawal, I.; Jha, S. Mitochondrial Dysfunction and Alzheimer's Disease: Role of Microglia. Front. Aging Neurosci. 2020, 12, 252. [CrossRef] [PubMed]

15. Szczechowiak, K.; Diniz, B.S.; Leszek, J. Diet and Alzheimer's dementia-Nutritional approach to modulate inflammation. Pharmacol. Biochem. Behav. 2019, 184, 172743. [CrossRef] [PubMed]

16. Pistollato, F.; Iglesias, R.C.; Ruiz, R.; Aparicio, S.; Crespo, J.; Lopez, L.D.; Manna, P.P.; Giampieri, F.; Battino, M. Nutritional patterns associated with the maintenance of neurocognitive functions and the risk of dementia and Alzheimer's disease: A focus on human studies. Pharmacol. Res. 2018, 131, 32-43. [CrossRef]

17. Wang, M.; Jiang, S.; Zhou, L.; Yu, F.; Ding, H.; Li, P.; Zhou, M.; Wang, K. Potential mechanisms of action of curcumin for cancer prevention: Focus on cellular signaling pathways and miRNAs. Int. J. Biol. Sci. 2019, 15, 1200. [CrossRef]

18. Hesari, A.; Azizian, M.; Sheikhi, A.; Nesaei, A.; Sanaei, S.; Mahinparvar, N.; Derakhshani, M.; Hedayt, P.; Ghasemi, F.; Mirzaei, H. Chemopreventive and therapeutic potential of curcumin in esophageal cancer: Current and future status. Int. J. Cancer 2019, 144, 1215-1226. [CrossRef]

19. Hassan, F.-u.; Rehman, M.S.-u.; Khan, M.S.; Ali, M.A.; Javed, A.; Nawaz, A.; Yang, C. Curcumin as an alternative epigenetic modulator: Mechanism of action and potential effects. Front. Genet. 2019, 10, 514. [CrossRef]

20. Panahi, Y.; Khalili, N.; Sahebi, E.; Namazi, S.; Karimian, M.S.; Majeed, M.; Sahebkar, A. Antioxidant effects of curcuminoids in patients with type 2 diabetes mellitus: A randomized controlled trial. Inflammopharmacology 2017, 25, 25-31. [CrossRef]

21. Abdollahi, E.; Momtazi, A.A.; Johnston, T.P.; Sahebkar, A. Therapeutic effects of curcumin in inflammatory and immune-mediated diseases: A nature-made jack-of-all-trades? J. Cell. Physiol. 2018, 233, 830-848. [CrossRef]

22. Rezaee, R.; Momtazi, A.A.; Monemi, A.; Sahebkar, A. Curcumin: A potentially powerful tool to reverse cisplatin-induced toxicity. Pharmacol. Res. 2017, 117, 218-227. [CrossRef]

23. Panahi, Y.; Kianpour, P.; Mohtashami, R.; Jafari, R.; Simental-Mendía, L.E.; Sahebkar, A. Efficacy and safety of phytosomal curcumin in non-alcoholic fatty liver disease: A randomized controlled trial. Drug Res. 2017, 67, 244-251. [CrossRef] [PubMed]

24. Cicero, A.F.; Colletti, A.; Bajraktari, G.; Descamps, O.; Djuric, D.M.; Ezhov, M.; Fras, Z.; Katsiki, N.; Langlois, M.; Latkovskis, G. Lipid-lowering nutraceuticals in clinical practice: Position paper from an International Lipid Expert Panel. Nutr. Rev. 2017, 75, 731-767. [CrossRef] [PubMed]

25. Keshavarzi, Z.; Shakeri, F.; Barreto, G.E.; Bibak, B.; Sathyapalan, T.; Sahebkar, A. Medicinal plants in traumatic brain injury: Neuroprotective mechanisms revisited. Biofactors 2019, 45, 517-535. [CrossRef] [PubMed]

26. Vaughn, A.R.; Branum, A.; Sivamani, R.K. Effects of turmeric (Curcuma longa) on skin health: A systematic review of the clinical evidence. Phytother. Res. 2016, 30, 1243-1264. [CrossRef] [PubMed]

27. Hewlings, S.J.; Kalman, D.S. Curcumin: A review of its' effects on human health. Foods 2017, 6, 92. [CrossRef] [PubMed]

28. Epelbaum, R.; Schaffer, M.; Vizel, B.; Badmaev, V.; Bar-Sela, G. Curcumin and gemcitabine in patients with advanced pancreatic cancer. Nutr. Cancer 2010, 62, 1137-1141. [CrossRef]

29. Sharifi-Rad, J.; Rayess, Y.E.; Rizk, A.A.; Sadaka, C.; Zgheib, R.; Zam, W.; Sestito, S.; Rapposelli, S.; Neffe-Skocińska, K.; Zielińska, D. Turmeric and its major compound curcumin on health: Bioactive effects and safety profiles for food, pharmaceutical, biotechnological and medicinal applications. Front. Pharmacol. 2020, 11. [CrossRef]

30. Ngo, S.T.; Truong, D.T.; Tam, N.M.; Nguyen, M.T. EGCG inhibits the oligomerization of amyloid beta (16-22) hexamer: Theoretical studies. J. Mol. Graph. Model. 2017, 76, 1-10. [CrossRef]

31. Qin, J.; Park, J.S.; Jo, D.G.; Cho, M.; Lee, Y. Curcumin-based electrochemical sensor of amyloid- $\beta$ oligomer for the early detection of Alzheimer's disease. Sens. Actuators B Chem. 2018, 273, 1593-1599. [CrossRef]

32. Huo, X.; Zhang, Y.; Jin, X.; Li, Y.; Zhang, L. A novel synthesis of selenium nanoparticles encapsulated PLGA nanospheres with curcumin molecules for the inhibition of amyloid $\beta$ aggregation in Alzheimer's disease. J. Photochem. Photobiol. B Biol. 2019, 190, 98-102. [CrossRef]

33. Yang, F.; Lim, G.P.; Begum, A.N.; Ubeda, O.J.; Simmons, M.R.; Ambegaokar, S.S.; Chen, P.P.; Kayed, R.; Glabe, C.G.; Frautschy, S.A. Curcumin inhibits formation of amyloid $\beta$ oligomers and fibrils, binds plaques, and reduces amyloid in vivo. J. Biol. Chem. 2005, 280, 5892-5901. [CrossRef] [PubMed] 
34. Garcia-Alloza, M.; Borrelli, L.; Rozkalne, A.; Hyman, B.T.; Bacskai, B.J. Curcumin labels amyloid pathology in vivo, disrupts existing plaques, and partially restores distorted neurites in an Alzheimer mouse model. J. Neurochem. 2007, 102, 1095-1104. [CrossRef] [PubMed]

35. Park, S.-Y.; Kim, D.S. Discovery of natural products from Curcuma l onga that protect cells from beta-amyloid insult: A drug discovery effort against Alzheimer's disease. J. Nat. Prod. 2002, 65, 1227-1231. [CrossRef] [PubMed]

36. Narlawar, R.; Pickhardt, M.; Leuchtenberger, S.; Baumann, K.; Krause, S.; Dyrks, T.; Weggen, S.; Mandelkow, E.; Schmidt, B. Curcumin-Derived Pyrazoles and Isoxazoles: Swiss Army Knives or Blunt Tools for Alzheimer's Disease? ChemMedChem 2008, 3, 165-172. [CrossRef] [PubMed]

37. Kim, D.S.; Park, S.-Y.; Kim, J.-Y. Curcuminoids from Curcuma longa L.(Zingiberaceae) that protect PC12 rat pheochromocytoma and normal human umbilical vein endothelial cells from $\beta$ A (1-42) insult. Neurosci. Lett. 2001, 303, 57-61. [CrossRef]

38. Wiatrak, B.; Kubis-Kubiak, A.; Piwowar, A.; Barg, E. PC12 Cell Line: Cell Types, Coating of Culture Vessels, Differentiation and Other Culture Conditions. Cells 2020, 9, 958. [CrossRef]

39. Fiala, M.; Liu, P.T.; Espinosa-Jeffrey, A.; Rosenthal, M.J.; Bernard, G.; Ringman, J.M.; Sayre, J.; Zhang, L.; Zaghi, J.; Dejbakhsh, S. Innate immunity and transcription of MGAT-III and Toll-like receptors in Alzheimer's disease patients are improved by bisdemethoxycurcumin. Proc. Natl. Acad. Sci. USA 2007, 104, 12849-12854. [CrossRef]

40. Mishra, S.; Mishra, M.; Seth, P.; Sharma, S.K. Tetrahydrocurcumin confers protection against amyloid $\beta$-induced toxicity. Neuroreport 2011, 22, 23-27. [CrossRef]

41. Thapa, A.; Jett, S.D.; Chi, E.Y. Curcumin attenuates amyloid- $\beta$ aggregate toxicity and modulates amyloid- $\beta$ aggregation pathway. ACS Chem. Neurosci. 2016, 7, 56-68. [CrossRef]

42. Salter, M.W.; Stevens, B. Microglia emerge as central players in brain disease. Nat. Med. 2017, 23, 1018. [CrossRef]

43. Perry, V.H.; Holmes, C. Microglial priming in neurodegenerative disease. Nat. Rev. Neurol. 2014, 10, 217-224. [CrossRef] [PubMed]

44. Gao, Y.; Zhuang, Z.; Lu, Y.; Tao, T.; Zhou, Y.; Liu, G.; Wang, H.; Zhang, D.; Wu, L.; Dai, H. Curcumin Mitigates Neuro-Inflammation by Modulating Microglia Polarization Through Inhibiting TLR4 Axis Signaling Pathway Following Experimental Subarachnoid Hemorrhage. Front. Neurosci. 2019, 13. [CrossRef] [PubMed]

45. Liu, Z.-J.; Li, Z.-H.; Liu, L.; Tang, W.-X.; Wang, Y.; Dong, M.-R.; Xiao, C. Curcumin attenuates beta-amyloid-induced neuroinflammation via activation of peroxisome proliferator-activated receptor-gamma function in a rat model of Alzheimer's disease. Front. Pharmacol. 2016, 7, 261. [CrossRef] [PubMed]

46. Zhang, Z.-J.; Zhao, L.-X.; Cao, D.-L.; Zhang, X.; Gao, Y.-J.; Xia, C. Curcumin inhibits LPS-induced CCL2 expression via JNK pathway in C6 rat astrocytoma cells. Cell. Mol. Neurobiol. 2012, 32, 1003-1010. [CrossRef]

47. Lin, M.-S.; Hung, K.-S.; Chiu, W.-T.; Sun, Y.-Y.; Tsai, S.-H.; Lin, J.-W.; Lee, Y.-H. Curcumin enhances neuronal survival in N-methyl-d-aspartic acid toxicity by inducing RANTES expression in astrocytes via PI-3K and MAPK signaling pathways. Prog. Neuro-Psychopharmacol. Biol. Psychiatry 2011, 35, 931-938. [CrossRef]

48. Tai, Y.-H.; Lin, Y.-Y.; Wang, K.-C.; Chang, C.-L.; Chen, R.-Y.; Wu, C.-C.; Cheng, I.H. Curcuminoid submicron particle ameliorates cognitive deficits and decreases amyloid pathology in Alzheimer's disease mouse model. Oncotarget 2018, 9, 10681. [CrossRef]

49. Lim, G.P.; Chu, T.; Yang, F.; Beech, W.; Frautschy, S.A.; Cole, G.M. The curry spice curcumin reduces oxidative damage and amyloid pathology in an Alzheimer transgenic mouse. J. Neurosci. 2001, 21, 8370-8377. [CrossRef]

50. Neddens, J.; Temmel, M.; Flunkert, S.; Kerschbaumer, B.; Hoeller, C.; Loeffler, T.; Niederkofler, V.; Daum, G.; Attems, J.; Hutter-Paier, B. Phosphorylation of different tau sites during progression of Alzheimer's disease. Acta Neuropathol. Commun. 2018, 6, 52. [CrossRef]

51. Li, Y.; Ding, R.; Ren, X.; Wen, G.; Dong, Z.; Yao, H.; Tan, Y.; Yu, H.; Wang, X.; Zhan, X. Long-term ketamine administration causes Tau protein phosphorylation and Tau protein-dependent AMPA receptor reduction in the hippocampus of mice. Toxicol. Lett. 2019, 315, 107-115. [CrossRef]

52. Harrison, T.M.; Maass, A.; Adams, J.N.; Du, R.; Baker, S.L.; Jagust, W.J. Tau deposition is associated with functional isolation of the hippocampus in aging. Nat. Commun. 2019, 10, 1-12. [CrossRef]

53. Novak, P.; Schmidt, R.; Kontsekova, E.; Kovacech, B.; Smolek, T.; Katina, S.; Fialova, L.; Prcina, M.; Parrak, V.; Dal-Bianco, P. Fundamant: An interventional 72-week phase 1 follow-up study of AADvac1, an active immunotherapy against tau protein pathology in Alzheimer's disease. Alzheimer's Res. Ther. 2018, 10, 1-16. [CrossRef]

54. Lin, M.T.; Beal, M.F. Mitochondrial dysfunction and oxidative stress in neurodegenerative diseases. Nature 2006, 443, 787-795. [CrossRef] [PubMed]

55. Honig, L.S.; Vellas, B.; Woodward, M.; Boada, M.; Bullock, R.; Borrie, M.; Hager, K.; Andreasen, N.; Scarpini, E.; Liu-Seifert, H. Trial of solanezumab for mild dementia due to Alzheimer's disease. N. Engl. J. Med. 2018, 378, 321-330. [CrossRef] [PubMed]

56. Rane, J.S.; Bhaumik, P.; Panda, D. Curcumin inhibits tau aggregation and disintegrates preformed tau filaments in vitro. J. Alzheimer's Dis. 2017, 60, 999-1014. [CrossRef] [PubMed]

57. Tang, M.; Taghibiglou, C. The mechanisms of action of curcumin in Alzheimer's disease. J. Alzheimer's Dis. 2017, 58, 1003-1016. [CrossRef]

58. Goozee, K.; Shah, T.; Sohrabi, H.R.; Rainey-Smith, S.; Brown, B.; Verdile, G.; Martins, R. Examining the potential clinical value of curcumin in the prevention and diagnosis of Alzheimer's disease. Br. J. Nutr. 2016, 115, 449-465. [CrossRef]

59. Yarza, R.; Vela, S.; Solas, M.; Ramirez, M.J. c-Jun N-terminal kinase (JNK) signaling as a therapeutic target for Alzheimer's disease. Front. Pharmacol. 2016, 6, 321. [CrossRef] 
60. Ma, Q.-L.; Zuo, X.; Yang, F.; Ubeda, O.J.; Gant, D.J.; Alaverdyan, M.; Teng, E.; Hu, S.; Chen, P.-P.; Maiti, P. Curcumin suppresses soluble tau dimers and corrects molecular chaperone, synaptic, and behavioral deficits in aged human tau transgenic mice. J. Biol. Chem. 2013, 288, 4056-4065. [CrossRef]

61. Huang, H.-C.; Tang, D.; Xu, K.; Jiang, Z.-F. Curcumin attenuates amyloid- $\beta$-induced tau hyperphosphorylation in human neuroblastoma SH-SY5Y cells involving PTEN/Akt/GSK-3 $\beta$ signaling pathway. J. Recept. Signal Transduct. 2014, 34, 26-37. [CrossRef]

62. Beal, M.F. Mitochondria take center stage in aging and neurodegeneration. Ann. Neurol. Off. J. Am. Neurol. Assoc. Child Neurol. Soc. 2005, 58, 495-505. [CrossRef]

63. Yamazaki, H.; Tanji, K.; Wakabayashi, K.; Matsuura, S.; Itoh, K. Role of the K eap1/N rf2 pathway in neurodegenerative diseases. Pathol. Int. 2015, 65, 210-219. [CrossRef] [PubMed]

64. Mythri, R.B.; Jagatha, B.; Pradhan, N.; Andersen, J.; Bharath, M.S. Mitochondrial complex I inhibition in Parkinson's disease: How can curcumin protect mitochondria? Antioxid. Redox Signal. 2007, 9, 399-408. [CrossRef] [PubMed]

65. Gao, C.; Wang, Y.; Sun, J.; Han, Y.; Gong, W.; Li, Y.; Feng, Y.; Wang, H.; Yang, M.; Li, Z. Neuronal mitochondria-targeted delivery of curcumin by biomimetic engineered nanosystems in Alzheimer's disease mice. Acta Biomater. 2020. [CrossRef] [PubMed]

66. Abrahams, S.; Haylett, W.L.; Johnson, G.; Carr, J.A.; Bardien, S. Antioxidant effects of curcumin in models of neurodegeneration, aging, oxidative and nitrosative stress: A review. Neuroscience 2019, 406, 1-21. [CrossRef] [PubMed]

67. Daverey, A.; Agrawal, S.K. Curcumin alleviates oxidative stress and mitochondrial dysfunction in astrocytes. Neuroscience 2016, 333, 92-103. [CrossRef] [PubMed]

68. Mandal, M.; Jaiswal, P.; Mishra, A. Role of curcumin and its nanoformulations in neurotherapeutics: A comprehensive review. J. Biochem. Mol. Toxicol. 2020, 34, e22478. [CrossRef]

69. Maiti, P.; Paladugu, L.; Dunbar, G.L. Solid lipid curcumin particles provide greater anti-amyloid, anti-inflammatory and neuroprotective effects than curcumin in the 5xFAD mouse model of Alzheimer's disease. BMC Neurosci. 2018, 19, 1-18. [CrossRef]

70. Botchway, B.O.; Moore, M.K.; Akinleye, F.O.; Iyer, I.C.; Fang, M. Nutrition: Review on the possible treatment for Alzheimer's disease. J. Alzheimer's Dis. 2018, 61, 867-883. [CrossRef]

71. Eghbaliferiz, S.; Farhadi, F.; Barreto, G.E.; Majeed, M.; Sahebkar, A. Effects of curcumin on neurological diseases: Focus on astrocytes. Pharmacol. Rep. 2020, 1-14.

72. Lin, L.; Li, C.; Zhang, D.; Yuan, M.; Chen, C.-h.; Li, M. Synergic Effects of Berberine and Curcumin on Improving Cognitive Function in an Alzheimer's Disease Mouse Model. Neurochem. Res. 2020, 1-12. [CrossRef]

73. Alamro, A.A.; Alsulami, E.A.; Almutlaq, M.; Alghamedi, A.; Alokail, M.; Haq, S.H. Therapeutic Potential of Vitamin D and Curcumin in an In Vitro Model of Alzheimer Disease. J. Cent. Nerv. Syst. Dis. 2020, 12. [CrossRef]

74. Liu, S.; Gao, J.; Zhu, M.; Liu, K.; Zhang, H.-L. Gut microbiota and dysbiosis in Alzheimer's disease: Implications for pathogenesis and treatment. Mol. Neurobiol. 2020, 57, 5026-5043. [CrossRef] [PubMed]

75. Reddy, V.P.; Aryal, P.; Robinson, S.; Rafiu, R.; Obrenovich, M.; Perry, G. Polyphenols in Alzheimer's Disease and in the Gut-Brain Axis. Microorganisms 2020, 8, 199. [CrossRef] [PubMed]

76. Zhuang, Z.; Yang, R.; Wang, W.; Qi, L.; Huang, T. Associations between gut microbiota and Alzheimer's disease, major depressive disorder, and schizophrenia. J. Neuroinflamm. 2020, 17, 1-9. [CrossRef] [PubMed]

77. Di Meo, F.; Margarucci, S.; Galderisi, U.; Crispi, S.; Peluso, G. Curcumin, gut microbiota, and neuroprotection. Nutrients 2019, 11, 2426. [CrossRef]

78. He, Y.; Li, B.; Sun, D.; Chen, S. Gut microbiota: Implications in Alzheimer's disease. J. Clin. Med. 2020, 9, 2042. [CrossRef]

79. Sun, Z.-Z.; Li, X.-Y.; Wang, S.; Shen, L.; Ji, H.-F. Bidirectional interactions between curcumin and gut microbiota in transgenic mice with Alzheimer's disease. Appl. Microbiol. Biotechnol. 2020, 104, 3507-3515. [CrossRef]

80. Carmody, R.N.; Turnbaugh, P.J. Host-microbial interactions in the metabolism of therapeutic and diet-derived xenobiotics. J. Clin. Investig. 2014, 124, 4173-4181. [CrossRef]

81. Zam, W. Gut microbiota as a prospective therapeutic target for curcumin: A review of mutual influence. J. Nutr. Metab. 2018, 2018, 1-11. [CrossRef]

82. Annunziata, G.; Arnone, A.; Ciampaglia, R.; Tenore, G.C.; Novellino, E. Fermentation of Foods and Beverages as a Tool for Increasing Availability of Bioactive Compounds. Focus on Short-Chain Fatty Acids. Foods 2020, 9, 999. [CrossRef]

83. Yong, C.C.; Yoon, Y.; Yoo, H.S.; Oh, S. Effect of lactobacillus fermentation on the anti-inflammatory potential of turmeric J. Microbiol. Biotechnol. 2019, 29, 1561-1569. [CrossRef] [PubMed]

84. Annunziata, G.; Jiménez, M.; Capó, X.; Moranta, D.; Arnone, A.; Tenore, G.; Sureda, A.; Tejada, S. Microencapsulation as a tool to counteract the typical low bioavailability of polyphenols in the management of diabetes. Food Chem. Toxicol. 2020, 111248. [CrossRef] [PubMed]

85. Ozkan, G.; Franco, P.; De Marco, I.; Xiao, J.; Capanoglu, E. A review of microencapsulation methods for food antioxidants: Principles, advantages, drawbacks and applications. Food Chem. 2019, 272, 494-506. [CrossRef] [PubMed]

86. Wang, S.; Chen, Y.; Liang, H.; Chen, Y.; Shi, M.; Wu, J.; Liu, X.; Li, Z.; Liu, B.; Yuan, Q. Intestine-specific delivery of hydrophobic bioactives from oxidized starch microspheres with an enhanced stability. J. Agric. Food Chem. 2015, 63, 8669-8675. [CrossRef] 
87. de Vries, R.; Stell, A.; Mohammed, S.; Hermanns, C.; Martinez, A.H.; Jetten, M.; van Apeldoorn, A. Bioengineering, biomaterials, and $\beta$-cell replacement therapy. In Transplantation, Bioengineering, and Regeneration of the Endocrine Pancreas; Elsevier: Amsterdam, The Netherlands, 2020; pp. 461-486.

88. Di, L.; Kerns, E. Blood-brain barrier. In Drug-Like Properties, 2nd ed.; Press, A., Ed.; Academic Press: Boston, MA, USA, 2020; pp. 141-159.

89. Chainoglou, E.; Hadjipavlou-Litina, D. Curcumin in Health and Diseases: Alzheimer's Disease and Curcumin Analogues, Derivatives, and Hybrids. Int. J. Mol. Sci. 2020, 21, 1975. [CrossRef]

90. Liao, L.; Shi, J.; Jiang, C.; Zhang, L.; Feng, L.; Liu, J.; Zhang, J. Activation of anti-oxidant of curcumin pyrazole derivatives through preservation of mitochondria function and Nrf2 signaling pathway. Neurochem. Int. 2019, 125, 82-90. [CrossRef]

91. Hagl, S.; Kocher, A.; Schiborr, C.; Kolesova, N.; Frank, J.; Eckert, G.P. Curcumin micelles improve mitochondrial function in neuronal PC12 cells and brains of NMRI mice-Impact on bioavailability. Neurochem. Int. 2015, 89, 234-242. [CrossRef]

92. Chojnacki, J.E.; Liu, K.; Yan, X.; Toldo, S.; Selden, T.; Estrada, M.; Rodríguez-Franco, M.I.; Halquist, M.S.; Ye, D.; Zhang, S. Discovery of 5-(4-hydroxyphenyl)-3-oxo-pentanoic acid [2-(5-methoxy-1H-indol-3-yl)-ethyl]-amide as a neuroprotectant for Alzheimer's disease by hybridization of curcumin and melatonin. ACS Chem. Neurosci. 2014, 5, 690-699. [CrossRef]

93. Noureddin, S.A.; El-Shishtawy, R.M.; Al-Footy, K.O. Curcumin analogues and their hybrid molecules as multifunctional drugs. Eur. J. Med. Chem. 2019, 182, 111631. [CrossRef]

94. Mythri, R.B.; Harish, G.; Dubey, S.K.; Misra, K.; Bharath, M.S. Glutamoyl diester of the dietary polyphenol curcumin offers improved protection against peroxynitrite-mediated nitrosative stress and damage of brain mitochondria in vitro: Implications for Parkinson's disease. Mol. Cell. Biochem. 2011, 347, 135-143. [CrossRef]

95. Okuda, M.; Fujita, Y.; Hijikuro, I.; Wada, M.; Uemura, T.; Kobayashi, Y.; Waku, T.; Tanaka, N.; Nishimoto, T.; Izumi, Y. PE859, A novel curcumin derivative, inhibits amyloid- $\beta$ and Tau aggregation, and ameliorates cognitive dysfunction in senescenceaccelerated mouse prone 8. J. Alzheimer's Dis. 2017, 59, 313-328. [CrossRef] [PubMed]

96. Clarkson, G.J.; Farrán, M.Á.; Claramunt, R.M.; Alkorta, I.; Elguero, J. The structure of the anti-aging agent J147 used for treating Alzheimer's disease. Acta Crystallogr. Sect. C: Struct. Chem. 2019, 75, 271-276. [CrossRef] [PubMed]

97. Fang, L.; Gou, S.; Liu, X.; Cao, F.; Cheng, L. Design, synthesis and anti-Alzheimer properties of dimethylaminomethyl-substituted curcumin derivatives. Bioorganic Med. Chem. Lett. 2014, 24, 40-43. [CrossRef] [PubMed]

98. Yanagisawa, D.; Ibrahim, N.F.; Taguchi, H.; Morikawa, S.; Hirao, K.; Shirai, N.; Sogabe, T.; Tooyama, I. Curcumin derivative with the substitution at C-4 position, but not curcumin, is effective against amyloid pathology in APP/PS1 mice. Neurobiol. Aging 2015, 36, 201-210. [CrossRef] [PubMed]

99. Villaflores, O.B.; Chen, Y.-J.; Chen, C.-P.; Yeh, J.-M.; Wu, T.-Y. Effects of curcumin and demethoxycurcumin on amyloid$\beta$ precursor and tau proteins through the internal ribosome entry sites: A potential therapeutic for Alzheimer's disease. Taiwan J. Obstet. Gynecol. 2012, 51, 554-564. [CrossRef] [PubMed]

100. Orlando, R.A.; Gonzales, A.M.; Royer, R.E.; Deck, L.M.; Vander Jagt, D.L. A chemical analog of curcumin as an improved inhibitor of amyloid Abeta oligomerization. PLoS ONE 2012, 7, e31869. [CrossRef]

101. Dolai, S.; Shi, W.; Corbo, C.; Sun, C.; Averick, S.; Obeysekera, D.; Farid, M.; Alonso, A.; Banerjee, P.; Raja, K. "Clicked" sugar-curcumin conjugate: Modulator of amyloid- $\beta$ and tau peptide aggregation at ultralow concentrations. ACS Chem. Neurosci. 2011, 2, 694-699. [CrossRef]

102. Chen, P.-T.; Hou, W.-C.; Yu, L.-C.; Chen, R.P.-Y. Polyhydroxycurcuminoids but not curcumin upregulate neprilysin and can be applied to the prevention of Alzheimer's disease. Sci. Rep. 2016, 6, 29760. [CrossRef]

103. Di Martino, R.M.C.; De Simone, A.; Andrisano, V.; Bisignano, P.; Bisi, A.; Gobbi, S.; Rampa, A.; Fato, R.; Bergamini, C.; Perez, D.I. Versatility of the curcumin scaffold: Discovery of potent and balanced dual BACE-1 and GSK-3ß inhibitors. J. Med. Chem. 2016, 59, 531-544. [CrossRef]

104. Lee, E.H.C.; Lim, S.S.C.; Yuen, K.H.; Lee, C.Y. Curcumin and a hemi-analogue with improved blood-brain barrier permeability protect against amyloid-beta toxicity in Caenorhabditis elegans via SKN-1/Nrf activation. J. Pharm. Pharmacol. 2019, 71, 860-868. [CrossRef]

105. Kochi, A.; Jin Lee, H.; M Vithanarachchi, S.; Padmini, V.; J Allen, M.; Hee Lim, M. Inhibitory activity of curcumin derivatives towards metal-free and metal-induced amyloid- $\beta$ aggregation. Curr. Alzheimer Res. 2015, 12, 415-423. [CrossRef] [PubMed]

106. Xiao, Z.; Zhang, A.; Lin, J.; Zheng, Z.; Shi, X.; Di, W.; Qi, W.; Zhu, Y.; Zhou, G.; Fang, Y. Telomerase: A target for therapeutic effects of curcumin and a curcumin derivative in A $\beta 1-42$ insult in vitro. PLoS ONE 2014, 9, e101251. [CrossRef] [PubMed]

107. Yan, J.; Hu, J.; Liu, A.; He, L.; Li, X.; Wei, H. Design, synthesis, and evaluation of multitarget-directed ligands against Alzheimer's disease based on the fusion of donepezil and curcumin. Bioorganic Med. Chem. 2017, 25, 2946-2955. [CrossRef] [PubMed]

108. Wan, Y.; Liang, Y.; Liang, F.; Shen, N.; Shinozuka, K.; Yu, J.-T.; Ran, C.; Quan, Q.; Tanzi, R.E.; Zhang, C. A Curcumin Analog Reduces Levels of the Alzheimer's Disease-Associated Amyloid- $\beta$ Protein by Modulating A $\beta$ PP Processing and Autophagy. J. Alzheimer's Dis. 2019, 72, 761-771. [CrossRef] [PubMed]

109. Morroni, F.; Sita, G.; Graziosi, A.; Ravegnini, G.; Molteni, R.; Paladini, M.S.; Dias, K.S.T.; dos Santos, A.F.; Viegas, C., Jr.; Camps, I. PQM130, a novel feruloyl-donepezil hybrid compound, effectively ameliorates the cognitive impairments and pathology in a mouse model of Alzheimer's disease. Front. Pharmacol. 2019, 10, 658. [CrossRef] [PubMed] 
110. Su, I.-J.; Chang, H.-Y.; Wang, H.-C.; Tsai, K.-J. A Curcumin Analog Exhibits Multiple Biologic Effects on the Pathogenesis of Alzheimer's Disease and Improves Behavior, Inflammation, and $\beta$-Amyloid Accumulation in a Mouse Model. Int. J. Mol. Sci. 2020, 21, 5459. [CrossRef]

111. Teleanu, D.M.; Chircov, C.; Grumezescu, A.M.; Volceanov, A.; Teleanu, R.I. Blood-brain delivery methods using nanotechnology. Pharmaceutics 2018, 10, 269. [CrossRef]

112. Barar, J.; Rafi, M.A.; Pourseif, M.M.; Omidi, Y. Blood-brain barrier transport machineries and targeted therapy of brain diseases. Bioimpacts 2016, 6, 225. [CrossRef]

113. Li, G.; Shao, K.; Umeshappa, C.S. Recent progress in blood-brain barrier transportation research. In Brain Targeted Drug Delivery System; Elsevier: Amsterdam, The Netherlands, 2019; pp. 33-51.

114. Erickson, M.A.; Banks, W.A. Neuroimmune axes of the blood-brain barriers and blood-brain interfaces: Bases for physiological regulation, disease states, and pharmacological interventions. Pharmacol. Rev. 2018, 70, 278-314. [CrossRef]

115. Pardridge, W.M. Drug transport across the blood-brain barrier. J. Cereb. Blood Flow Metab. 2012, 32, 1959-1972. [CrossRef]

116. Huang, M.; Gu, X.; Gao, X. Brain Targeted Drug Delivery System; Elsevier: Amsterdam, The Netherlands, 2019.

117. D'Souza, A.A. Solid lipid nanoparticles: A modern approach for the treatment of neurodegenerative diseases. In Nanotechnology: Applications in Energy, Drug and Food; Springer: Berlin/Heidelberg, Germany, 2019; pp. 209-225.

118. Lajoie, J.M.; Shusta, E.V. Targeting receptor-mediated transport for delivery of biologics across the blood-brain barrier. Annu. Rev. Pharmacol. Toxicol. 2015, 55, 613-631. [CrossRef] [PubMed]

119. D'souza, A.A.; Devarajan, P.V. Asialoglycoprotein receptor mediated hepatocyte targeting-Strategies and applications. J. Control. Release 2015, 203, 126-139. [CrossRef] [PubMed]

120. Zhou, Y.; Peng, Z.; Seven, E.S.; Leblanc, R.M. Crossing the blood-brain barrier with nanoparticles. J. Control. Release 2018, 270, 290-303. [CrossRef] [PubMed]

121. Grabrucker, A.M.; Ruozi, B.; Belletti, D.; Pederzoli, F.; Forni, F.; Vandelli, M.A.; Tosi, G. Nanoparticle transport across the blood brain barrier. Tissue Barriers 2016, 4, e1153568. [CrossRef] [PubMed]

122. O'Keeffe, E.; Campbell, M. Modulating the paracellular pathway at the blood-brain barrier: Current and future approaches for drug delivery to the CNS. Drug Discov. Today: Technol. 2016, 20, 35-39.

123. Fakhoury, M.; Takechi, R.; Al-Salami, H. Drug permeation across the blood-brain barrier: Applications of Nanotechnology. Br. J. Med. Med Res. 2015, 6, 547-556. [CrossRef]

124. Bhatia, S. Nanoparticles types, classification, characterization, fabrication methods and drug delivery applications. In Natural Polymer Drug Delivery Systems; Springer: Berlin/Heidelberg, Germany, 2016; pp. 33-93.

125. Subasi, A. Use of artificial intelligence in Alzheimer's disease detection. In Artificial Intelligence in Precision Health; Elsevier: Amsterdam, The Netherlands, 2020; pp. 257-278.

126. Bilal, M.; Barani, M.; Sabir, F.; Rahdar, A.; Kyzas, G.Z. Nanomaterials for the treatment and diagnosis of Alzheimer's disease: An overview. NanoImpact 2020, 100251. [CrossRef]

127. Rubab, M.; Shahbaz, H.M.; Olaimat, A.N.; Oh, D.-H. Biosensors for rapid and sensitive detection of Staphylococcus aureus in food. Biosens. Bioelectron. 2018, 105, 49-57. [CrossRef]

128. Zhang, K.; Yang, Q.; Fan, Z.; Zhao, J.; Li, H. Platelet-driven formation of interface peptide nano-network biosensor enabling a non-invasive means for early detection of Alzheimer's disease. Biosens. Bioelectron. 2019, 145, 111701. [CrossRef]

129. Carneiro, P.; Morais, S.; do Carmo Pereira, M. Biosensors on the road to early diagnostic and surveillance of Alzheimer's disease. Talanta 2020, 211, 120700. [CrossRef]

130. Chan, H.-N.; Xu, D.; Ho, S.-L.; He, D.; Wong, M.S.; Li, H.-W. Highly sensitive quantification of Alzheimer's disease biomarkers by aptamer-assisted amplification. Theranostics 2019, 9, 2939. [CrossRef] [PubMed]

131. Syedmoradi, L.; Ahmadi, A.; Norton, M.L.; Omidfar, K. A review on nanomaterial-based field effect transistor technology for biomarker detection. Microchim. Acta 2019, 186, 739. [CrossRef] [PubMed]

132. Gupta, J.; Fatima, M.T.; Islam, Z.; Khan, R.H.; Uversky, V.N.; Salahuddin, P. Nanoparticle formulations in the diagnosis and therapy of Alzheimer's disease. Int. J. Biol. Macromol. 2019, 130, 515-526. [CrossRef] [PubMed]

133. Choudhary, N.; Hwang, S.; Choi, W. Carbon nanomaterials: A review. In Handbook of Nanomaterials Properties; Springer: Berlin/Heidelberg, Germany, 2014; pp. 709-769.

134. Ashrafizadeh, M.; Mohammadinejad, R.; Kailasa, S.K.; Ahmadi, Z.; Afshar, E.G.; Pardakhty, A. Carbon dots as versatile nanoarchitectures for the treatment of neurological disorders and their theranostic applications: A review. Adv. Colloid Interface Sci. 2020, 278, 102123. [CrossRef]

135. Härtig, W.; Mages, B.; Aleithe, S.; Nitzsche, B.; Altmann, S.; Barthel, H.; Krueger, M.; Michalski, D. Damaged neocortical perineuronal nets due to experimental focal cerebral ischemia in mice, rats and sheep. Front. Integr. Neurosci. 2017, 11, 15. [CrossRef]

136. Ritchie, M.E.; Phipson, B.; Wu, D.; Hu, Y.; Law, C.W.; Shi, W.; Smyth, G.K. limma powers differential expression analyses for RNA-sequencing and microarray studies. Nucleic Acids Res. 2015, 43, e47. [CrossRef]

137. Liu, F.; Wang, W.; Sang, J.; Jia, L.; Lu, F. Hydroxylated single-walled carbon nanotubes inhibit a $\beta 42$ fibrillogenesis, disaggregate mature fibrils, and protect against A $\beta 42$-induced cytotoxicity. ACS Chem. Neurosci. 2018, 10, 588-598. [CrossRef] 
138. Neely, A.; Perry, C.; Varisli, B.; Singh, A.K.; Arbneshi, T.; Senapati, D.; Kalluri, J.R.; Ray, P.C. Ultrasensitive and highly selective detection of Alzheimer's disease biomarker using two-photon Rayleigh scattering properties of gold nanoparticle. ACS Nano 2009, 3, 2834-2840. [CrossRef]

139. Ramassamy, C.; Longpré, F.; Christen, Y. Ginkgo biloba extract (EGb 761) in Alzheimer's disease: Is there any evidence? Curr. Alzheimer Res. 2007, 4, 253-262. [CrossRef]

140. Sanati, M.; Khodagholi, F.; Aminyavari, S.; Ghasemi, F.; Gholami, M.; Kebriaeezadeh, A.; Sabzevari, O.; Hajipour, M.J.; Imani, M.; Mahmoudi, M. Impact of Gold Nanoparticles on Amyloid $\beta$-Induced Alzheimer's Disease in a Rat Animal Model: Involvement of STIM Proteins. ACS Chem. Neurosci. 2019, 10, 2299-2309. [CrossRef]

141. Suga, K.; Lai, Y.-C.; Faried, M.; Umakoshi, H. Direct observation of amyloid $\beta$ behavior at phospholipid membrane constructed on gold nanoparticles. Int. J. Anal. Chem. 2018, 2018. [CrossRef] [PubMed]

142. Tanifum, E.A.; Ghaghada, K.; Vollert, C.; Head, E.; Eriksen, J.L.; Annapragada, A. A novel liposomal nanoparticle for the imaging of amyloid plaque by magnetic resonance imaging. J. Alzheimer's Dis. 2016, 52, 731-745. [CrossRef] [PubMed]

143. Kuo, Y.-C.; Chen, I.-Y.; Rajesh, R. Use of functionalized liposomes loaded with antioxidants to permeate the blood-brain barrier and inhibit $\beta$-amyloid-induced neurodegeneration in the brain. J. Taiwan Inst. Chem. Eng. 2018, 87, 1-14. [CrossRef]

144. Pansieri, J.; Plissonneau, M.; Stransky-Heilkron, N.; Dumoulin, M.; Heinrich-Balard, L.; Rivory, P.; Morfin, J.-F.; Toth, E.; Saraiva, M.J.; Allémann, E. Multimodal imaging Gd-nanoparticles functionalized with Pittsburgh compound B or a nanobody for amyloid plaques targeting. Nanomedicine 2017, 12, 1675-1687. [CrossRef]

145. Cantore, M. New Perspective in Alzheimer's Disease-Theranostic Strategy. Biomed. J. Sci. Tech. Res. 2019, 15, 11108-11111. [CrossRef]

146. Viola, K.L.; Sbarboro, J.; Sureka, R.; De, M.; Bicca, M.A.; Wang, J.; Vasavada, S.; Satpathy, S.; Wu, S.; Joshi, H. Towards non-invasive diagnostic imaging of early-stage Alzheimer's disease. Nat. Nanotechnol. 2015, 10, 91-98. [CrossRef]

147. Singh, Y.P.; Pandey, A.; Vishwakarma, S.; Modi, G. A review on iron chelators as potential therapeutic agents for the treatment of Alzheimer's and Parkinson's diseases. Mol. Divers. 2019, 23, 509-526. [CrossRef]

148. Zand, Z.; Khaki, P.A.; Salihi, A.; Sharifi, M.; Nanakali, N.M.Q.; Alasady, A.A.; Aziz, F.M.; Shahpasand, K.; Hasan, A.; Falahati, M. Cerium oxide NPs mitigate the amyloid formation of $\alpha$-synuclein and associated cytotoxicity. Int. J. Nanomed. 2019, 14, 6989. [CrossRef]

149. Kakkar, V.; Kumari, P.; Adlakha, S.; Kaur, I.P. Curcumin and Its Nanoformulations as Therapeutic for Alzheimer's Disease. In Nanobiotechnology in Neurodegenerative Diseases; Springer: Berlin/Heidelberg, Germany, 2019; pp. $343-367$.

150. Joseph, A.; Wood, T.; Chen, C.-C.; Corry, K.; Snyder, J.M.; Juul, S.E.; Parikh, P.; Nance, E. Curcumin-loaded polymeric nanoparticles for neuroprotection in neonatal rats with hypoxic-ischemic encephalopathy. Nano Res. 2018, 11, 5670-5688. [CrossRef]

151. Gao, C.; Chu, X.; Gong, W.; Zheng, J.; Xie, X.; Wang, Y.; Yang, M.; Li, Z.; Gao, C.; Yang, Y. Neuron tau-targeting biomimetic nanoparticles for curcumin delivery to delay progression of Alzheimer's disease. J. Nanobiotechnol. 2020, 18, 1-23. [CrossRef]

152. Zhang, L.; Yang, S.; Wong, L.R.; Xie, H.; Ho, P.C. In Vitro and In Vivo Comparison of Curcumin-Encapsulated Chitosan-Coated Poly(lactic-co-glycolic acid) Nanoparticles and Curcumin/Hydroxypropyl- $\beta$-Cyclodextrin Inclusion Complexes Administered Intranasally as Therapeutic Strategies for Alzheimer's Disease. Mol. Pharm. 2020, 17, 4256-4269. [CrossRef] [PubMed]

153. Yavarpour-Bali, H.; Ghasemi-Kasman, M.; Pirzadeh, M. Curcumin-loaded nanoparticles: A novel therapeutic strategy in treatment of central nervous system disorders. Int. J. Nanomed. 2019, 14, 4449. [CrossRef] [PubMed]

154. Sadegh Malvajerd, S.; Azadi, A.; Izadi, Z.; Kurd, M.; Dara, T.; Dibaei, M.; Sharif Zadeh, M.; Akbari Javar, H.; Hamidi, M. Brain delivery of curcumin using solid lipid nanoparticles and nanostructured lipid carriers: Preparation, optimization, and pharmacokinetic evaluation. ACS Chem. Neurosci. 2018, 10, 728-739. [CrossRef] [PubMed]

155. Sadegh Malvajerd, S.; Izadi, Z.; Azadi, A.; Kurd, M.; Derakhshankhah, H.; Sharifzadeh, M.; Akbari Javar, H.; Hamidi, M. Neuroprotective potential of curcumin-loaded nanostructured lipid carrier in an animal model of Alzheimer's disease: Behavioral and biochemical evidence. J. Alzheimer's Dis. 2019, 69. [CrossRef] [PubMed]

156. Yang, R.; Zheng, Y.; Wang, Q.; Zhao, L. Curcumin-loaded chitosan-bovine serum albumin nanoparticles potentially enhanced A $\beta 42$ phagocytosis and modulated macrophage polarization in Alzheimer's disease. Nanoscale Res. Lett. 2018, 13, 330. [CrossRef] [PubMed]

157. Doggui, S.; Sahni, J.K.; Arseneault, M.; Dao, L.; Ramassamy, C. Neuronal uptake and neuroprotective effect of curcumin-loaded PLGA nanoparticles on the human SK-N-SH cell line. J. Alzheimer's Dis. 2012, 30, 377-392. [CrossRef]

158. Angelova, A.; Drechsler, M.; Garamus, V.M.; Angelov, B. Liquid crystalline nanostructures as pegylated reservoirs of omega-3 polyunsaturated fatty acids: Structural insights toward delivery formulations against neurodegenerative disorders. ACS Omega 2018, 3, 3235-3247. [CrossRef]

159. Wei, L.; Li, X.; Guo, F.; Liu, X.; Wang, Z. Structural properties, in vitro release and radical scavenging activity of lecithin based curcumin-encapsulated inverse hexagonal (HII) liquid crystals. Colloids Surf. A Physicochem. Eng. Asp. 2018, 539, 124-131. [CrossRef]

160. Daraee, H.; Etemadi, A.; Kouhi, M.; Alimirzalu, S.; Akbarzadeh, A. Application of liposomes in medicine and drug delivery. Artif. CellsNanomed. Biotechnol. 2016, 44, 381-391. [CrossRef]

161. Lombardo, D.; Calandra, P.; Bellocco, E.; Laganà, G.; Barreca, D.; Magazù, S.; Wanderlingh, U.; Kiselev, M.A. Effect of anionic and cationic polyamidoamine (PAMAM) dendrimers on a model lipid membrane. Biochim. Biophys. Acta Biomembr. 2016, 1858, 2769-2777. [CrossRef] 
162. Attia, A.B.E.; Ong, Z.Y.; Hedrick, J.L.; Lee, P.P.; Ee, P.L.R.; Hammond, P.T.; Yang, Y.-Y. Mixed micelles self-assembled from block copolymers for drug delivery. Curr. Opin. Colloid Interface Sci. 2011, 16, 182-194. [CrossRef]

163. Ji, S.; Lin, X.; Yu, E.; Dian, C.; Yan, X.; Li, L.; Zhang, M.; Zhao, W.; Dian, L. Curcumin-loaded mixed micelles: Preparation, characterization, and in vitro antitumor activity. J. Nanotechnol. 2018, 2018, 1-9. [CrossRef]

164. Coisne, C.; Tilloy, S.; Monflier, E.; Wils, D.; Fenart, L.; Gosselet, F. Cyclodextrins as emerging therapeutic tools in the treatment of cholesterol-associated vascular and neurodegenerative diseases. Molecules 2016, 21, 1748. [CrossRef] [PubMed]

165. Ramdani, L.; Bourboulou, R.; Belkouch, M.; Jebors, S.; Tauran, Y.; Parizot, C.; Suwinska, K.; Coleman, A.; Duyckaerts, C.; Lazar, A. Multifunctional Curcumin-Nanocarriers Based on Host-Guest Interactions for Alzheimer Disease Diagnostic. J. Nanomed. Nanotechnol. 2015, 6,1.

166. Chen, M.; Du, Z.-Y.; Zheng, X.; Li, D.-L.; Zhou, R.-P.; Zhang, K. Use of curcumin in diagnosis, prevention, and treatment of Alzheimer's disease. Neural Regen. Res. 2018, 13, 742. [PubMed]

167. Wang, F.; Wu, X.; Wang, F.; Liu, S.; Jia, Z.; Yang, J. The sensitive fluorimetric method for the determination of curcumin using the enhancement of mixed micelle. J. Fluoresc. 2006, 16, 53-59. [CrossRef] [PubMed]

168. Tu, P.; Fu, H.; Cui, M. Compounds for imaging amyloid- $\beta$ deposits in an Alzheimer's brain: A patent review. Expert Opin. Ther. Pat. 2015, 25, 413-423. [CrossRef]

169. Si, G.; Zhou, S.; Xu, G.; Wang, J.; Wu, B.; Zhou, S. A curcumin-based NIR fluorescence probe for detection of amyloid-beta (A $\beta$ ) plaques in Alzheimer's disease. Dye. Pigment. 2019, 163, 509-515. [CrossRef]

170. Chibhabha, F.; Yang, Y.; Ying, K.; Jia, F.; Zhang, Q.; Ullah, S.; Liang, Z.; Xie, M.; Li, F. Non-invasive optical imaging of retinal $\mathrm{A} \beta$ plaques using curcumin loaded polymeric micelles in APP swe/PS1 $\Delta \mathrm{E} 9$ transgenic mice for the diagnosis of Alzheimer's disease. J. Mater. Chem. B 2020, 8, 7438-7452. [CrossRef]

171. Singh, A.; Mahajan, S.D.; Kutscher, H.L.; Kim, S.; Prasad, P.N. Curcumin-Pluronic Nanoparticles: A Theranostic Nanoformulation for Alzheimer's Disease. Crit. Rev. Biomed. Eng. 2020, 48.

172. Qin, J.; Jo, D.G.; Cho, M.; Lee, Y. Monitoring of early diagnosis of Alzheimer's disease using the cellular prion protein and poly (pyrrole-2-carboxylic acid) modified electrode. Biosens. Bioelectron. 2018, 113, 82-87. [CrossRef] [PubMed] 